\title{
Middle Triassic high-K calc-alkaline effusive and pyroclastic rocks from the Zagorje-Mid-Transdanubian Zone (Mt. Kuna Gora; NW Croatia): mineralogy, petrology, geochemistry and tectono- magmatic affinity
}

\author{
Damir Slovenec ${ }^{1}$ and Branimir Šegvić ${ }^{2}$ \\ ${ }^{1}$ Croatian Geological Survey \\ Sachsova 2, 10000 Zagreb, Croatia. Slovenec E-mail: damir.slovenec@hgi-cgs.hr \\ ${ }^{2}$ Department of Geosciences, Texas Tech University \\ 1200 Memorial Circle, Lubbock 79409 TX, U.S.A.
}

\begin{abstract}
This study uses mineralogical, petrological, geochemical, and $\mathrm{Sr}$ and $\mathrm{Nd}$ isotope data along with $\mathrm{K}$-Ar ages to infer the petrogenesis and geodynamic evolution of Middle Triassic high-K calc-alkaline lavas and their associated pyroclastics of Mt. Kuna Gora in NW Croatia. Their analogue mineralogy and bulk-rock geochemistry testify to the coeval origin of both rock types. Sanidine and plagioclase accompanied by minor augite and Ti-bearing magnetite are the major phases found in a matrix of devitrified volcanic glass and plagioclase microlites. Hydrothermal and diagenetic processes in the pyroclastics originated the formation of chlorite and white mica, and mixed-layer clay minerals, respectively. Petrography reveals the following crystallization order: spinel $\rightarrow$ clinopyroxene $\rightarrow$ plagioclase $\rightarrow$ alkali-feldspar $\pm F e-T i$ oxides. Geochemical and isotopic data suggests that the studied rocks had a complex origin that included the contamination of subduction-generated magmas by lithospheric mantle melts. This presumes an interplay between fertile arc mantle, subducted continental crust, and depleted or ocean island basalts-like mantle. A low degree of crustal contamination stands as a last step in the formation of such "hybrid" magmas. The subducted Paleotethyan oceanic lithosphere went through processes of partial melting at depths of $\sim 45-49 \mathrm{~km}$ and pressures of $\leq 1.6 \mathrm{GPa}$ and fractionation that produced melts which gave rise to the studied rocks. In the model we are proposing herein such formed partial melts are related to the demise of the northward subduction of the Paleotethys oceanic lithosphere during the Early to Middle Triassic epoch, which is consistent with an active, ensialic mature volcanic arc developing along Laurussian southern active margins.
\end{abstract}

\section{INTRODUCTION}

The volcanic activity within the Tethyan realm was widespread during the Triassic. Middle Triassic magmatism has been reported in the Alps, Carpathians, Dinarides and Hellenides (e.g. Beccaluva et al., 2005;
Casetta et al., 2019; Castellarin et al., 1988; Goričan et al., 2005; Graciansky et al., 2011; Kovács et al., 2011; Harangi et al., 1996; Knežević et al., 1998; de Min et al., 2020; Pamić, 1984; Pe-Piper, 1998; Pomonis et al., 2004; Smirčić et al., 2018; Storck et al., 2018; Velledits, 2006; and references therein). Different types of lavas and

(C) D. Slovenec, B. Šegvić, 2021 CC BY-SA 
pyroclastic material as well as rare intrusive rocks mark this magmatic event (e.g. Bianchini et al., 2018; Bonadiman et al., 1994; Casetta et al., 2018; Castorina et al., 2020; Lustrino et al., 2011, 2019; De Min et al., 2020; Saccani et al., 2015; Sloman, 1989; Slovenec et al., 2020; Storck et al., 2018; Trubelja et al., 2004; and references therein). The Middle Triassic magmatism has been related to the formation of the Adriatic-Dinaridic carbonate platform(s) and its subsequent disintegration (e.g. Castellarin et al., 1988; Kovács, 1989; McCann, 2008; Philip et al., 1995; Robertson, 2007; Storck et al., 2018; Vlahović et al., 2005; and reference therein). Yet, the geodynamic framework and tectonomagmatic evolution of the area separating Gondwana and Laurasia (the Southern Alps, Dinarides, Hellenides, and the Alpine-Carpathian Belt) remain controversial (e.g. Bortolotti and Principi, 2005; Bortolotti et al., 2013; De Min et al., 2020; Neubauer et al., 2019; Şengör, 1984; Stampfli and Borel, 2004; Stampfli et al., 2013; Zulauf et al., 2018). The magmatism of the Middle to Upper Triassic period has been related to compressional, extensional and/or transtensional geodynamic processes (e.g. Abbas et al., 2018; Beccaluva et al., 2005; Bonadiman et al., 1994; Castellarin et al., 1988; Castorina et al., 2020; Csontos and Vörös, 2004; Lustrino et al., 2019; Schmid et al., 2008, 2019; Stampfli et al., 2002; Storck et al., 2018; and reference therein). Two hypotheses have emerged over the years i) that the continental rifting caused the magmatic events (e.g. Aljinović et al., 2010; Crisci et al., 1984; Harangi et al., 1996; Knežević et al., 1998; Kovács, 1992; De Min et al., 2020; Pamić, 1984; Pamić and Balen, 2005; del Piaz and Martin, 1998; Saccani et al., 2015; Velledits, 2004, 2006; and references therein) and ii) that the magmatism was originated by convergent plate movements triggered by the subduction of the Paleotethys lithosphere (e.g. Bébien et al., 1978; Bianchini et al., 2018; Bonadiman et al., 1994; Casetta et al., 2018; Cassinis et al., 2008; Castellarin et al., 1980, 1988; Castorina et al., 2020; Grimes et al., 2015; Kovács, 1992; Obenholzner, 1991; Schmid et al., 2004; Slovenec et al., 2020; Smirčić et al., 2018; Stampfli and Borel, 2002, 2004; Storck et al., 2019; Trubelja et al., 2004; Zanetti et al., 2013; and references therein). The subduction and back-arc extension processes in the AlpineCarpathian-Dinaride realm produced diverse magmatisms, among which the calc-alkaline one dominated (e.g. Arculus and Powell, 1986; Avanzinelli et al., 2012; Elliott et al., 1997; Hawkesworth et al., 1991, 1993; Keller, 1982; Pearce, 1982, 1983; Pearce and Parkinson, 1993). Although the calc-alkaline magma was likely coeval with the active subduction it also might have been linked to adiabatic melting of an old, subduction-imprinted, mantle wedge; alternatively the calc-alkaline magma stems from the melting of the continental lithosphere affected by subduction processes (e.g. Cameron et al., 2003; Hawkesworth et al., 1995; Hooper et al., 1995; Johnson et al., 1978; Lustrino et al., 2019; Saccani et al., 2015). Considering a diverse magmatic activity and complex geodynamic processes documented along the continental margins of an emerging Adriatic-Dinaridic carbonate platform(s) in the western part of the Tethys Ocean, research on volcanic and volcanosedimentary successions is of key importance to explain multiple lithospheric processes.

The Middle Triassic igneous events of the southernmost segment of the geotectonic unit of Southern Alps (sensu Schmid et al., 2008) or the SW portion of the ZagorjeMid-Transdanubian Zone (ZMTDZ; sensu Pamić and Tomljenović, 1998) (Fig. 1A, B), are manifested in the volcanic-volcaniclastic sequences of Mt. Strahinjščica, Mt. Desinić Gora, Mt. Kuna Gora (Fig. 1C), Mt. Ravna Gora and northern slopes of Mt. Ivanščica. These successions, that sometimes are interstratified with siliciclastic and carbonate sediments, are made of basaltic to rhyolitic lavas and pyroclastic rocks, largely fine-grained and thoroughly altered (e.g. Marci et al., 1982, 1984; Šimunić and Šimunić, 1979, 1997; Šimunić, 1992). Heretofore research on Middle Triassic effusive and pyroclastic rocks of Mt. Kuna Gora was limited to a field survey for the geological map of Socialist Federal Republic of Yugoslavia, scale 1:100,000 (Aničić and Jureša, 1984; Fig. 1C), which included a basic petrographic rock characterization. Studies on analogue rocks of the neighboring Strahinjščica and Ivanščica mountains, also only contain the basic petrographic characterization (e.g. Golub and Brajdić, 1968, 1970; Golub et al., 1969; Goričan et al., 2005; Marci et al., 1982, 1984). One exception is a recent study on the Upper Anisian volcano-sedimentary succession of Mt. Ivanščica by Slovenec et al. (2020) that reports the origin, geodynamic significance, and diagenetic history of pyroclastics and associated chert.

In this contribution, we use mineralogical, petrographical, geochemical, and isotope data of representative samples of effusive and pyroclastic rocks from Mt. Kuna Gora in order to infer the petrogenesis of these effusive and pyroclastic rocks and constrain the period and geotectonic environment in which they formed.

\section{GEOLOGICAL SETTING}

The mountains of Kuna Gora, Strahinjščica and northern slopes of Mt. Ivanščica render a continuous series of the North Croatian mountains with an E-W elongation. These mountains are the most southern portion of the geotectonic unit of the Southern Alps (sensu Schmid et al., 2008; Fig. 1A). This unit is situated south of the Periadriatic Line and its eastern continuation, the Balaton Line; i.e. south of the ALCAPA (Alpine-Carpathian-Pannonian) Mega-Unit and was derived from continental crustal domains (e.g. Harangi et al., 1996; Haas and Kovács, 2001; Schmid et al., 


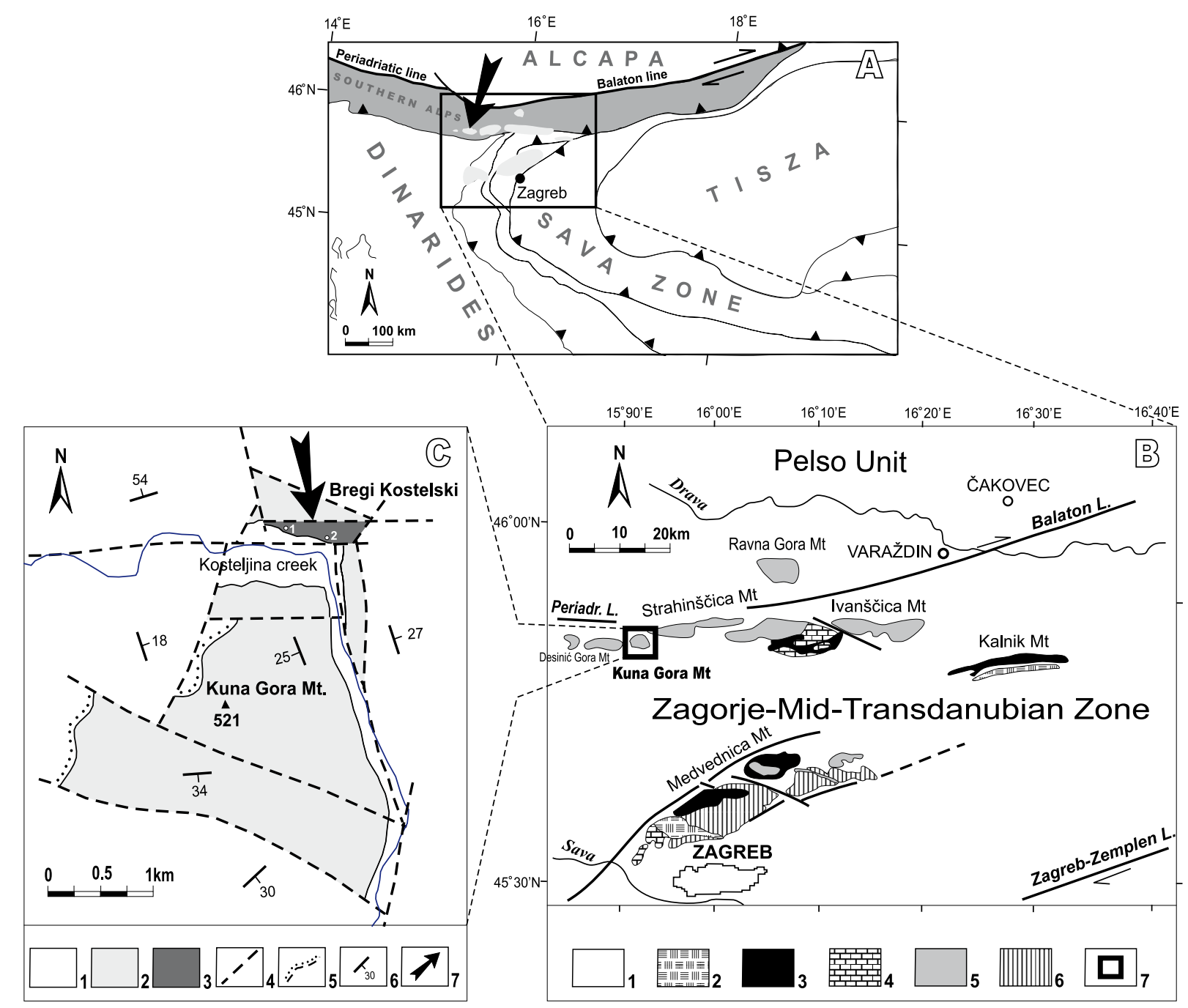

FIGURE 1. A) Geotectonic map of the major tectonic units (simplified after Schmid et al., 2008). Black arrow indicates the location of Mt. Kuna Gora. ALCAPA = Adria derived far-travelled nappes Alps and W. Carpathians. B) Geological map of the Croatian part of the Zagorje-Mid-Trandanubian Zone (slightly modified after Pamić and Tomlienović, 1998). Legend: 1= Quaternary and Neogene fill of the Pannonian Basin; 2= Upper CretaceousPaleocene flysch; 3= Ophiolitic mélange (Kalnik Unit); 4= Upper Triassic platform carbonates; 5= Upper Paleozoic and Triassic clastites and carbonates interlayered with lavas and tuffs; $6=$ Paleozoic-Triassic metamorphic complex (Medvednica Unit); 7= Location of C. C) Geological map of the Mt. Kuna Gora (simplified after Aničić and Jureša, 1984). Legend: $1=$ Quaternary and Tertiary deposits; $2=$ Dolomites, dolomitic breccia, dolomitic limestones (Middle Triassic); 3= Andesitic basalts, andesite-basaltic tuffs/ignimbrites (Middle Triassic; Ladinian); 4= Normal faults; 5= Discordance line, tectonic-erosion discordance; $6=$ Strike and dip of beds; $7=$ Location of study area.

2008). The above-mentioned North Croatian mountains are commonly referred to as the Intra-Pannonian Inselgebirges (Slovenec et al., 2011), which are part of the southwestern segment of the Zagorje-Mid-Transdanubian Zone (ZMTDZ) (sensu Pamić and Tomljenović, 1998; Fig. 1B) or Sava Unit (Fig. 1A) (sensu Haas et al., 2000). The ZMTDZ strikes in the NE-SW direction for $\sim 120 \mathrm{~km}$ between the two regional fault systems: the Zagreb-Zemplen Line to the south and the Periadriatic-Balaton Line to the north. The ZMTDZ is characterized by mixed Alpine-Dinaridic tectonostratigraphic and tectonometamorphic units (e.g. Haas et al., 2000; Haas and Kovács, 2001; Pamić and Tomljenović, 1998; Pamić, 2002; Slovenec and Lugović, 2009; Slovenec et al., 2011; Tari and Pamić, 1998) and its origin is still being debated.
The Mt. Kuna Gora is made of Middle Triassic carbonate rocks (dolomite, dolomitic breccia, dolomitic limestone) disconformably overlain by Cenozoic deposits (Fig. 1C). In the northern slopes of Mt. Kuna Gora in the area of Bregi Kostelski, Middle Triassic lavas and associated subordinately represented pyroclastic rocks crop out in an area of about $0.3 \mathrm{~km}^{2}$ (Fig. 1C). Their contacts with the coeval carbonate rocks (dolomitic limestones, dolomites) and Tertiary clastites are tectonic. The analyzed effusive rocks are disconformably overlain by Quaternary alluvial deposits. The studied rocks are found as massive fine-grained lavas and associated tuffs and ignimbrites(?) (Fig. 2A, B). Only exceptionally, a meter-size and angular "exotic" rocks are found in the lavas (Fig. 2D). These rocks 

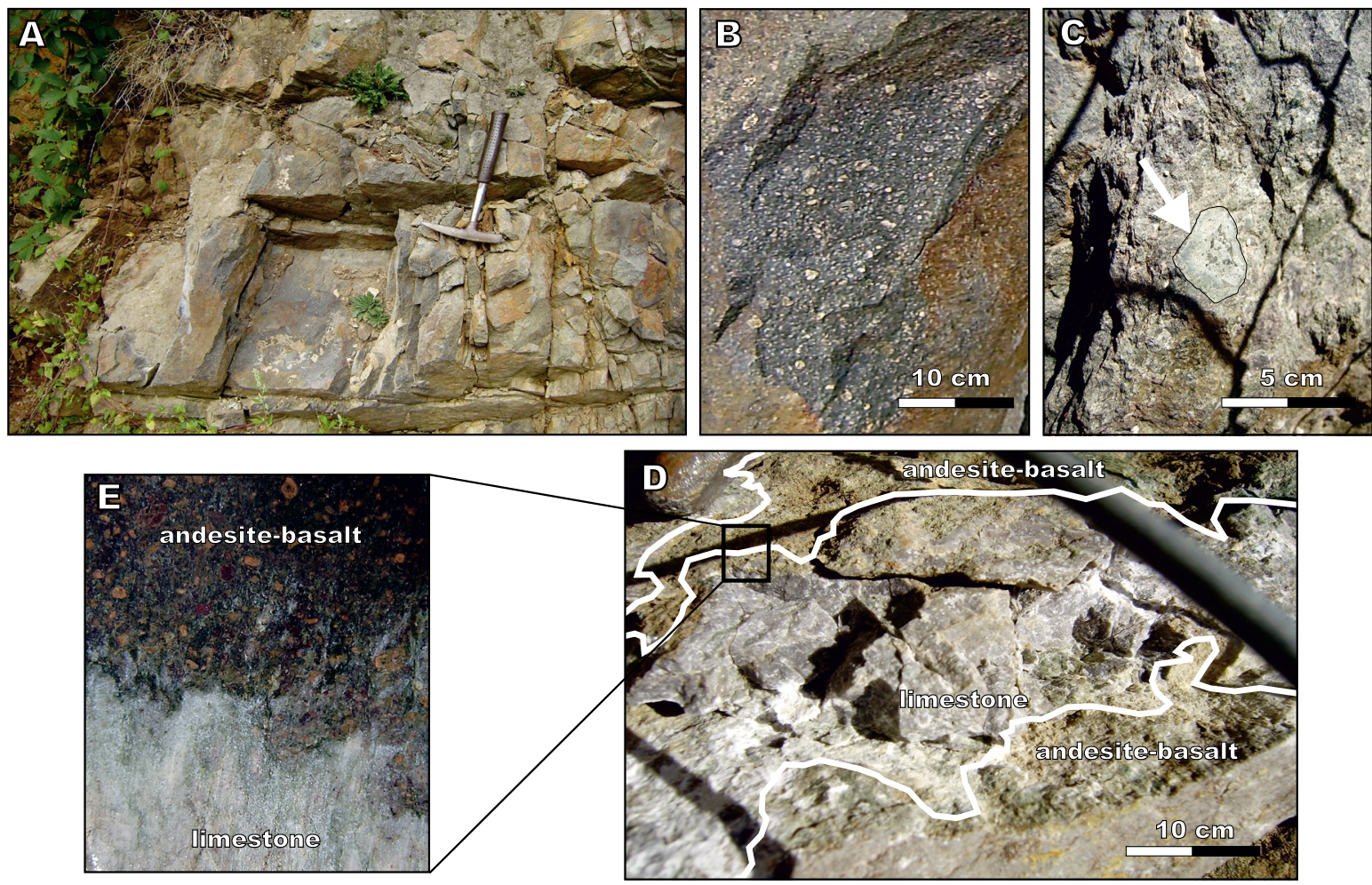

FIGURE 2. A) Massive, high-K calc-alcaline basalt and pyroclastics (tuffs) of analogue chemistry. B) Pyroclastics. C) Subrounded autoclast in andesitebasalt. D) Anisian (Middle Triassic) limestone in volcanic rock. E) Contact between the andesite-basalt and the Anisian limestone.

are made of fine-grained microcrystalline marine limestone of Anisian age. The marine carbonate mud must have been incorporated into the lava prior to complete lithification, as can be inferred from the preserved "active" contacts (see Fig. 2D). The deposition of carbonate mud must have taken place along the slopes of local relief where disintegrated and fragmented portions of a subsided carbonate platform might have been present. The relation between the lavas and the limestone rocks suggests that the volcanic activity was coeval with the marine carbonate sedimentation during the Late Anisian.

Similar effusive and pyroclastic rocks found elsewhere in the mountains of NW Croatia are all interbeded with Middle Triassic marine sediments (e.g. Goričan et al., 2005; Halamić, 1998; Marci et al., 1982, 1984; Šimunić and Šimunić, 1979; Šimunić, 1992; Slovenec et al., 2020). The volcanic activity of that period was characterized by submarine andesite to basaltic lava flows accompanied by multiple explosive eruptions of volcanic material. The Middle Triassic volcano-sedimentary succession from the ZMTDZ may be correlated with the Triassic volcanosedimentary successions of the Maliak-Meliata arcback-arc system (e.g. Goričan et al., 2005) and analogue successions from the Dinarides (e.g. Pamić, 1984, 1997; Smirčić et al., 2018, 2020; Trubelja et al., 2004).

\section{ANALYTICAL TECHNIQUES}

The mineral composition of two representative samples was analyzed at the Institute of Geosciences (University of Heidelberg, Germany) using a CAMECA SX51 electron microprobe equipped with five wavelength-dispersive spectrometers. Measurements were performed using an accelerating voltage of $15 \mathrm{kV}$, beam current of $20 \mathrm{nA}$, beam size of $\sim 1 \mu \mathrm{m}$ (for feldspars $10 \mu \mathrm{m}$ ) and 10 s counting time for all elements. Natural oxides and silicates were used as standards and for calibration. Raw data was corrected for matrix effects with the PAP algorithm (Pouchou and Pichoir, 1984, 1985) implemented by CAMECA. Calculations of the structural chemical formulas were undertaken using a software package PETERAKI designed by Hans-Peter Meyer (Institute of Geosciences, Heidelberg; hans-peter. meyer@geow.uni-heidelberg.de). This Excel based solution provides information on the error on formula unit cations. The software has been designed to calculate the formulas of standard petrogenetic phases. To calculate formulas of minor minerals, additional information on the total cation and oxygen content and $\mathrm{Fe}^{2+} / \mathrm{Fe}^{3+}$ distribution was required.

Bulk-rock powders for chemical analyses of seven effusive and pyroclastic samples were analyzed by Inductively Coupled Plasma Optical Emission Spectroscopy 
(ICP-OES) for major elements, and Inductively Coupled Plasma Mass Spectrometry (ICP-MS) for trace elements at Bureau Veritas Laboratories (Vancouver, BC, Canada). International mafic rocks were used as standards. Major element and trace element concentrations were measured with accuracy and precision better than $\pm 1 \%$ and $\pm 5 \%$, respectively. It is $3 \sigma$ at 10 times detection limit.

$\mathrm{Nd}$ and Sr isotopic composition of two bulk rock samples were measured at the Research Center for Petrography and Geochemistry (CRPG, Vandœuvre-les-Nancy, France) using a Triton Plus mass spectrometer. Normalizing ratios of ${ }^{86} \mathrm{Sr} /{ }^{88} \mathrm{Sr}=0.1194$ and ${ }^{146} \mathrm{Nd} /{ }^{144} \mathrm{Nd}=0.7219$ were assumed. The ${ }^{87} \mathrm{Sr} /{ }^{86} \mathrm{Sr}$ ratio for the NBS $987 \mathrm{Sr}$ standard for the period of measurement was $0.710242 \pm 0.000030$ $(2 \sigma)$. The ${ }^{143} \mathrm{Nd} /{ }^{144} \mathrm{Nd}$ ratio for the La Jolla standard was $0.5118451 \pm 0.000010(2 \sigma)$. Total procedural blanks were $\sim 500$ and 150 pg for $\mathrm{Sr}$ and $\mathrm{Nd}$, respectively. Python ${ }^{\mathrm{TM}}$ programing language (numpy package) was used to calculate the Monte Carlo propagation error through 10,000 iterations for ${ }^{147} \mathrm{Sm} /{ }^{144} \mathrm{Nd},{ }^{143} \mathrm{Nd} /{ }^{144} \mathrm{Nd}_{(\mathrm{t})},{ }^{87} \mathrm{Rb}^{186} \mathrm{Sr}$ and ${ }^{87} \mathrm{Sr} /{ }^{86} \mathrm{Sr}_{(\mathrm{t})}$ ratios.

The K-Ar age data was measured on K-feldspar separated from basalt sample $\mathrm{TsKg}-1$. K-feldspar was separated by an electromagnetic separator and standard heavy liquid techniques and finally was purified by hand picking under a binocular microscope. The $\mathrm{K}$ concentration and $\mathrm{Ar}$ analysis were determined by ICP and isotope dilution procedure on noble gas mass spectrometry, respectively. The analyses were performed at the Activation Laboratories (Ancaster, ON, Canada). For Ar analysis the aliquot of the sample is weighted into an $\mathrm{Al}$ container, loaded into the sample system of the extraction unit, and degassed at $\sim 100^{\circ} \mathrm{C}$ for 2 days to remove surface gases. The argon is extracted from the sample in a double vacuum furnace at $1700^{\circ} \mathrm{C}$. Argon concentration is determined using isotope dilution with an ${ }^{38} \mathrm{Ar}$ spike, which is introduced to the sample system prior to each extraction. The extracted gases are cleaned up in a two-step purification system. Then, pure Ar is introduced into a magnetic sector mass spectrometer (Reinolds type) with Varian CH5 magnet. The ion source has an axial design (Baur-Signer source), which provides more than $90 \%$ transmission and extremely small isotopic mass-discrimination. Measured Ar isotope ratios are corrected for mass-discrimination and atmospheric $\mathrm{Ar}$ is removed by assuming that all ${ }^{36} \mathrm{Ar}$ originated from air only. The concentration of radiogenic ${ }^{40} \mathrm{Ar}$ is calculated using the ${ }^{38} \mathrm{Ar}$ spike concentration. After each analysis, the extraction temperature is elevated to $1800^{\circ} \mathrm{C}$ for a few minutes and the furnace is prepared for the next analysis. For $\mathrm{K}$-analysis, a sample aliquot was weighted into a graphite crucible with lithium metaborate/tetraborate flux and fussed using a LECO induction furnace. The fusion bead is dissolved with acid. Standards, blanks and sample were analyzed by an ICP Spectrometer.
X-ray diffraction (XRD) was carried out on a set of three representative tuff samples. For that purpose the material was firstly gently crushed and powdered in an agate mortar and was thereupon placed in the sample holder. The material was analyzed with a Bruker D8-Advanced diffractometer installed at Texas Tech University (Lubbock, TX, United States of America) and run using a step scan in the Bragg-Brentano geometry with $\mathrm{CuK} \alpha$ radiation. The measurement settings were $45 \mathrm{kV}$ and $40 \mathrm{~mA}$ with sample mounts scanned from 3 to $70^{\circ} 2 \theta$. Measurements were completed under air-dried conditions and a counting time of $2.5 \mathrm{~s}$ per $0.02^{\circ} 2 \theta$. Lastly, the peaks of XRD patterns were interpreted and compared with the whole-rock geochemistry generated from ICP-MS to ensure geological fluidity. The Bruker DIFFRAC.EVA diffraction suite was used to analyze diffraction data.

\section{PETROGRAPHY AND MINERAL CHEMISTRY}

The effusive and pyroclastic rocks of Mt. Kuna Gora occur in the form of massive lavas (Fig. 2A). These rocks are associated with irregularly interstratified (up to $10 \mathrm{~cm}$ ) pyroclastic rocks (Fig. 2B). Both rock types have the same mineral composition (Figs. 3; 4A-F) and mineral phase chemistry (Table 1). The lavas display porphyritic to glomeroporphyritic seriate textures, homogenous to fluidal structures, indicating a flow of lava (Fig. 4E). The pyroclastic rocks are represented by vitro-crystalloclastic and rarely litho-crystalloclastic ashflow tuffs (ignimbrites?) of vitroclastic texture (Tišljar, 2004 and references therein). The subrounded lithoclasts of effusive and pyroclastic rocks in tuffs vary in size from 0.5 to $4 \mathrm{~cm}$, and the subangular autoclasts that can be observed in the lavas are up to $5 \mathrm{~cm}$ in size. (Figs. $2 \mathrm{C}$; 4D). Effusive and pyroclastic rocks are largely made (modal composition up to $45 \mathrm{vol} . \%$ ) of homogenous to slightly sericitized and albitized, subhedral to rarely euhedral phenocrysts or crystalloclasts/porphyroclasts

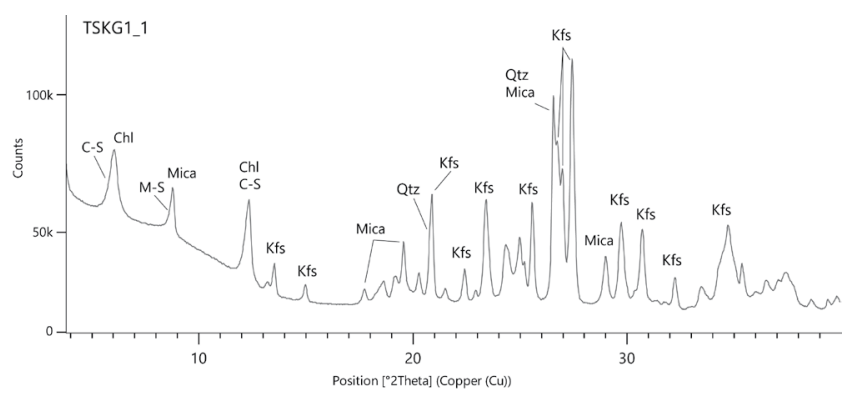

FIGURE 3. X-ray diffraction pattern showing the mineralogy of Mt. Kuna Gora tuffs. Mineral abbreviations after Kretz (1983): C-S= ChloriteSmectite, $\mathrm{Chl}=$ Chlorite, $\mathrm{M}-\mathrm{S}=$ Mica-Smectite, $\mathrm{Kfs}=\mathrm{K}$-feldspar, Qtz= Quartz. 

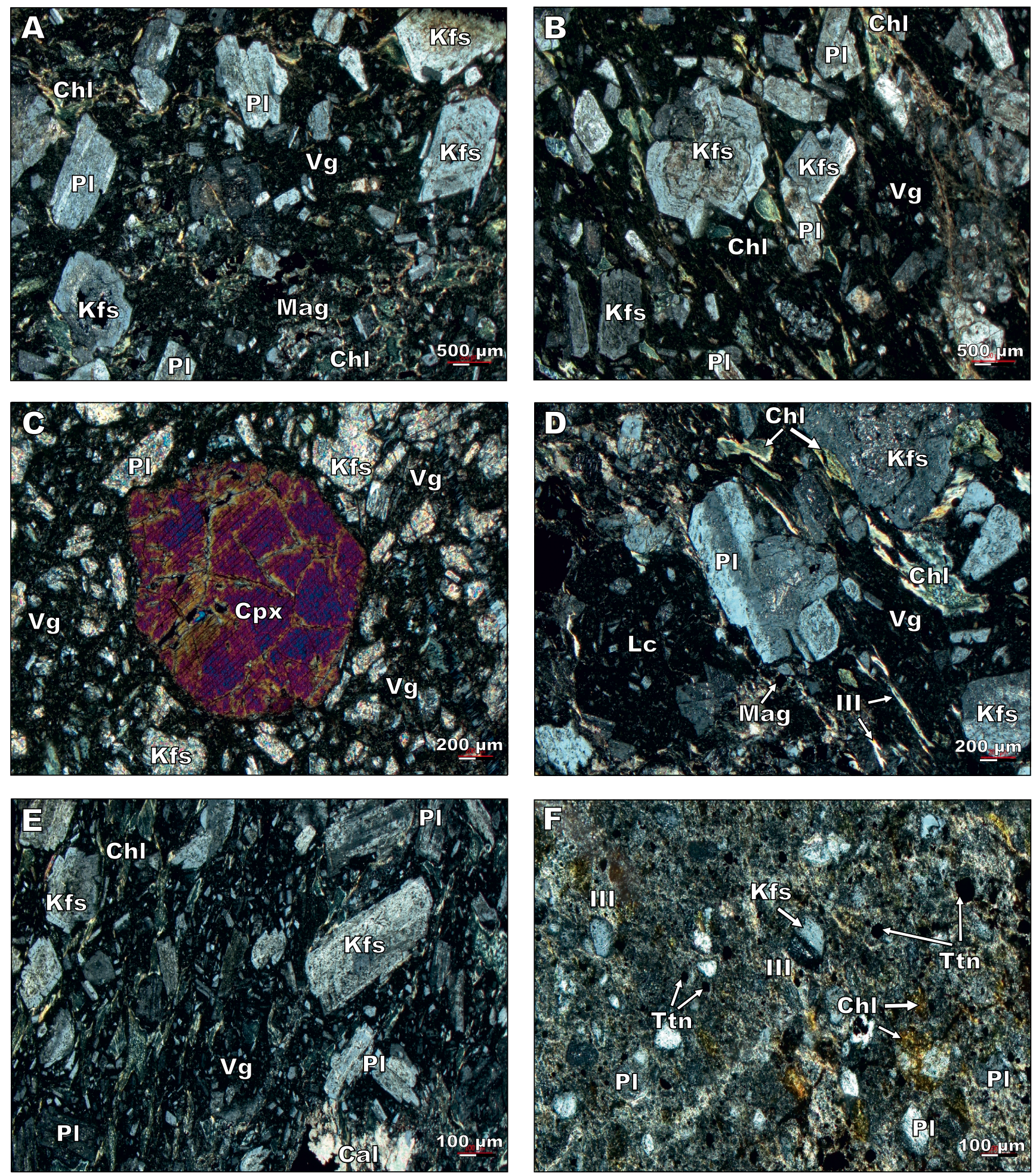

FIGURE 4. Photomicrographs of thin sections of effusive and pyroclastic rocks of Mt. Kuna Gora. A-E) Porfiric/glomeroporfiric andesite-basaltic lavas $(\mathrm{N}+)$.F) Vitro-cristaloclastic andesite-basaltic tuffs $(\mathrm{N}+)$. Mineral abbreviations after Kretz (1983): Cal= Calcite, Chl= Chlorite, Cpx= Clinopyroxene, $\mathrm{III}=$ Illite, $\mathrm{Kfs}=\mathrm{K}$-feldspar, Mag= Magnetite, $\mathrm{Pl}=$ Plagioclase, $\mathrm{Ttn}=$ Titanite. $\mathrm{LC}=$ Lithoclaste, $\mathrm{Vg}=$ Volcanic glass . 

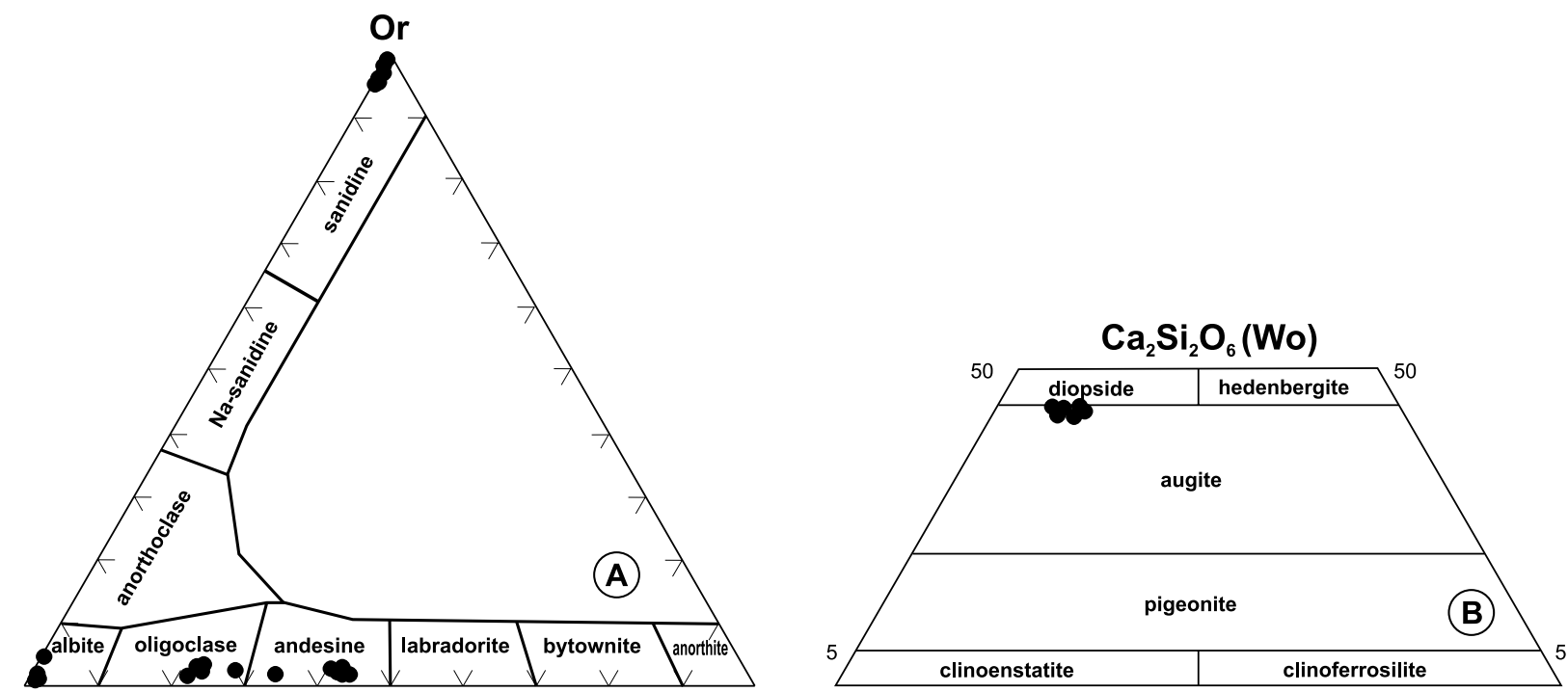

$\mathrm{Ab}$

An

$\mathrm{Mg}_{2} \mathrm{Si}_{2} \mathrm{O}_{6}$ (En)

$\mathrm{Fe}_{2} \mathrm{Si}_{2} \mathrm{O}_{6}$ (Fs)
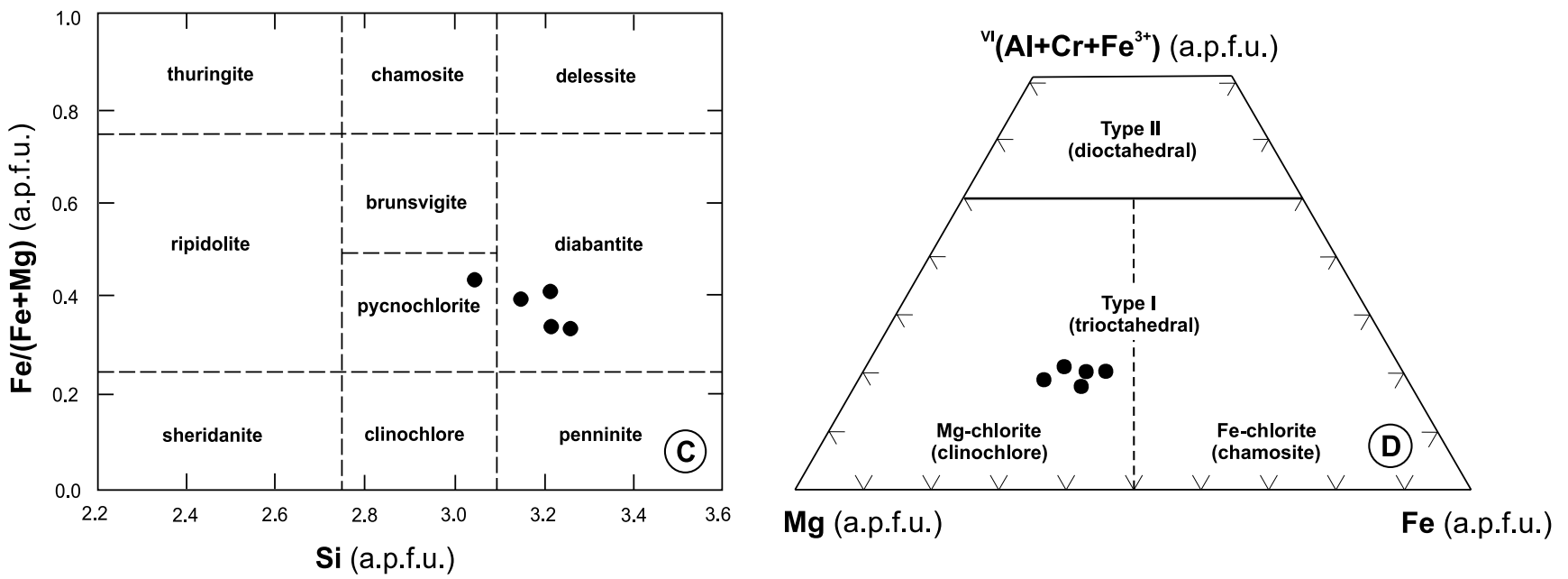

FIGURE 5. Classification diagrams of effusive and pyroclastic rocks from Mt. Kuna Gora. A) feldspar (Ab-An-Or plot; Dana et al., 1993; Deer et al., 1992) B) Pyroxene (En-Wo-Fs ( $\mathrm{Mg}_{2} \mathrm{Si}_{2} \mathrm{O}_{6}-\mathrm{Ca}_{2} \mathrm{Si}_{2} \mathrm{O}_{6}-\mathrm{Fe}_{2} \mathrm{Si}_{2} \mathrm{O}_{6}$ ) plot; Morimoto, 1988). C-D) Chlorite [Fe/(Fe+Mg)-Si plot (after Hey, 1954 adapted to Sun et al., 2019); Mg-Fe-Vl $\left(\mathrm{Al}^{+} \mathrm{Cr}^{+} \mathrm{Fe}^{3+}\right)$ plot (Zane and Weiss, 1998)].

(in pyroclastics) of alkali-feldspar $\left(\mathrm{An}_{0.0} \mathrm{Ab}_{1.1-3.7} \mathrm{Or}_{96.3-98.9}\right.$; Fig. 5A) up to $3 \mathrm{~mm}$ in size (Fig. 4A-E). Albitization of alkali-feldspar is due to water-rock interaction in an early stage of material deposition/emplacement (e.g. Hövelmann et al., 2010; Kaur et al., 2015). The abundant lath shaped polysynthetic twinning plagioclase $\left(\mathrm{An}_{22.6-45.2}\right.$; Fig. $\left.5 \mathrm{~A}\right)$ found in phenocrysts/glomerocrysts and crystalloclasts/ porphyroclasts in lavas and pyroclastics, respectively, is slightly sericitized and/or pervasively albitized $\left(\mathrm{An}_{0.2-2.0}\right.$; Fig. 4A-E). Rare phenocrysts of homogenous subhedral clinopyroxene (up to $1.5 \mathrm{~mm}$ in size) occurre in these rocks. Their composition corresponds to augite $\left(\mathrm{Wo}_{44.8-45.3} \mathrm{En} 4_{3.6-}\right.$ ${ }_{47.3} \mathrm{Fs}_{7.5-11.7}$; Fig. 4C; 5B) with high content of $\mathrm{Al}_{2} \mathrm{O}_{3}$ (4.175.72wt.\%), $\mathrm{Cr}_{2} \mathrm{O}_{3}$ (0.21-0.76wt.\%) and $\mathrm{Mg \#} \mathrm{(84.6-89.8).}$ The $\mathrm{Al}^{\mathrm{VI}} / \mathrm{Al}^{\mathrm{IV}}$ varies between 0.53 and 1.17 . Fine-grained chlorite (diabantite and pycnocnlorite, Hey, 1954; Fig. 5C or Mg-chlorite (clinochlore), Zane and Weiss, 1998; Fig, $5 \mathrm{D}$ ) is a common secondary phase developed in the matrix of the analyzed effusive and pyroclastic rocks (Fig. 4A-F). Millimeter-scale vesicles are commonly filled with flaky chlorite of analogue chemistry and/or white mica, whereas fine-grained quartz occurs only sporadically. White mica refers to a group of light-colored phyllosilicate minerals such as muscovite, paragonite, margarite, and celadonite (Parry, 1984). Accessory phases are Ti-bearing magnetite $\left(\mathrm{TiO}_{2}=5.18-15.58 \mathrm{wt} . \% ; \mathrm{FeO}=36.25-44.88 \mathrm{wt} . \%\right)$, zircon, apatite, secondary Fe-bearing Ti-oxide (rutile? $\mathrm{TiO}_{2}=$ 98.12wt.\%; $\mathrm{FeO}=2.90 \mathrm{wt} . \%)$, ilmenite, hematite and illite (Fig. 4A-B; Table 2). Ti-bearing magnetite may be featured by Fe-Ti oxide (rutile?) extracted along its lamellas (Fig. 6). 
Petrographic data suggests the following crystallization order: spinel $\rightarrow$ clinopyroxene $\rightarrow$ plagioclase $\rightarrow$ alkalifeldspar $\pm \mathrm{Fe}-\mathrm{Ti}$ oxides. The microcrystalline volcanic rock matrix is holocrystalline to hypocrystalline and is made of devitrified volcanic glass and microlites of plagioclase/ albite and alkali-feldspar with some minor ferromagnesian phases (Fig. 4). In the pyroclastic rocks, volcanic glass is the dominant component of the matrix (Fig. 4F). The glassy matrix has been completely altered into a mixture of fine-grained chlorite and white mica (Figs. 3; 4D, F), which likely resulted from high-temperature alterations (e.g. Tillick et al., 2001; Wang et al., 2018). XRD analyses further revealed the presence of chlorite-smectite and micasmectite (Fig. 3), both attributed to the opening of $10 \AA$ and $14 \AA$ phyllosilicates during low-temperature eogenetic alterations (Millot, 1971; Zanoni et al., 2016).

\section{GEOTHERMOBAROMETRIC ESTIMATIONS}

Estimates on crystallization conditions of andesitebasalt lavas of Mt. Kuna Gora are based either on clinopyroxene phase chemistry, clinopyroxene-wholerock or alkali-feldspar-whole-rock analyses, which are representative of melt composition. Accordingly, the maximal crystallization temperatures of augite were estimated to fit the range from 880 to $910( \pm 30)^{\circ} \mathrm{C}$ (Lindsey, 1983), while the geobarometer of Nimis (1999) and Nimis and Ulmer (1998) provides equilibration pressures of 1.02 to $1.62( \pm 0.2) \mathrm{GPa}$. Slightly higher crystallization temperature of clinopyroxene $\left(1076-1098^{\circ} \mathrm{C}\right)$, along with the more consistent and equilibrated pressure span (1.51-1.58GPa), were calculated using the geothermobarometer of Neave and Putirka (2017). Estimated pressures put constraints on crystallization depths of analyzed andesite-basalts at about $45-49 \mathrm{~km}$, which is inconsistent with genesis in deeper portions of an ensialic volcanic arc. Conversely, maximal crystallization temperatures of late magmatic alkali feldspar were estimated to fit the range of 618 to $672^{\circ} \mathrm{C}$ $\left(\mathrm{K}_{\mathrm{D}(\mathrm{Ab}-\mathrm{An})}=0.15-0.23 ; \mathrm{H}_{2} \mathrm{O}=3.7-4.6\right.$; geothermometer of Putirka, 2008), which corroborates the idea of an abrupt ascent of viscous andesitic melt followed by a rapid and massive crystallization of low-temperature mineral phases in upper lithospheric portions. The temperatures of chlorite formation were between 181.7 and $253.8^{\circ} \mathrm{C}$ (Cathelineau, 1988; Jowett, 1991) and 124.9 to $154.5^{\circ} \mathrm{C}$ (Kranidiotis and MacLean, 1987), which corresponds to very-low grade hydrothermal alteration processes.

\section{BULK-ROCK CHEMISTRY}

The silica concentration ranges representative analyses of the rock suites vary within a narrow range $\left(\mathrm{SiO}_{2}=48.40\right.$ 50.95 wt.\%), which is typical of mafic rocks (Cox et al., 1979). Potassium content, on the other hand, is high $\left(\mathrm{K}_{2} \mathrm{O}=\right.$ 8.21-9.62wt.\%), $\mathrm{Na}_{2} \mathrm{O}$ is low (0.13-0.81wt.\%), and $\mathrm{TiO}_{2}$ ranges from 0.91 to 1.46 wt.\% (Table 2). Samples are $\mathrm{SiO}_{2}-$ saturated with CIPW (Cross Iddings Pirson Washington) normative quartz content (1.24-6.35\%) and orthoclase content (up to $61.28 \%$ ). The Loss On Ignition value (LOI) is between 3.84 and $7.01 \mathrm{wt} . \%$, which points to the medium level of sea-floor hydrothermal alteration (e.g. Polat et al., 2002; Polat and Hofmann, 2003). The mobility of certain trace elements has been tested by plotting their abundances against $\mathrm{Zr}$ concentration (not shown) as a differentiation index (e.g. Pearce, 1975; Shervais, 1982; Staudigel et al., 1996). Low-level mobilization of some Large Ion Lithophile Elements (LILE), such as Cs, Rb, $\mathrm{K}$ and $\mathrm{Ba}$, has been documented. Conversely, High Field Strength Elements (HFSE) like Th, Nb, Ta, Ti, Hf, P, Y and Rare Earth Elements (REE) appear to have remained
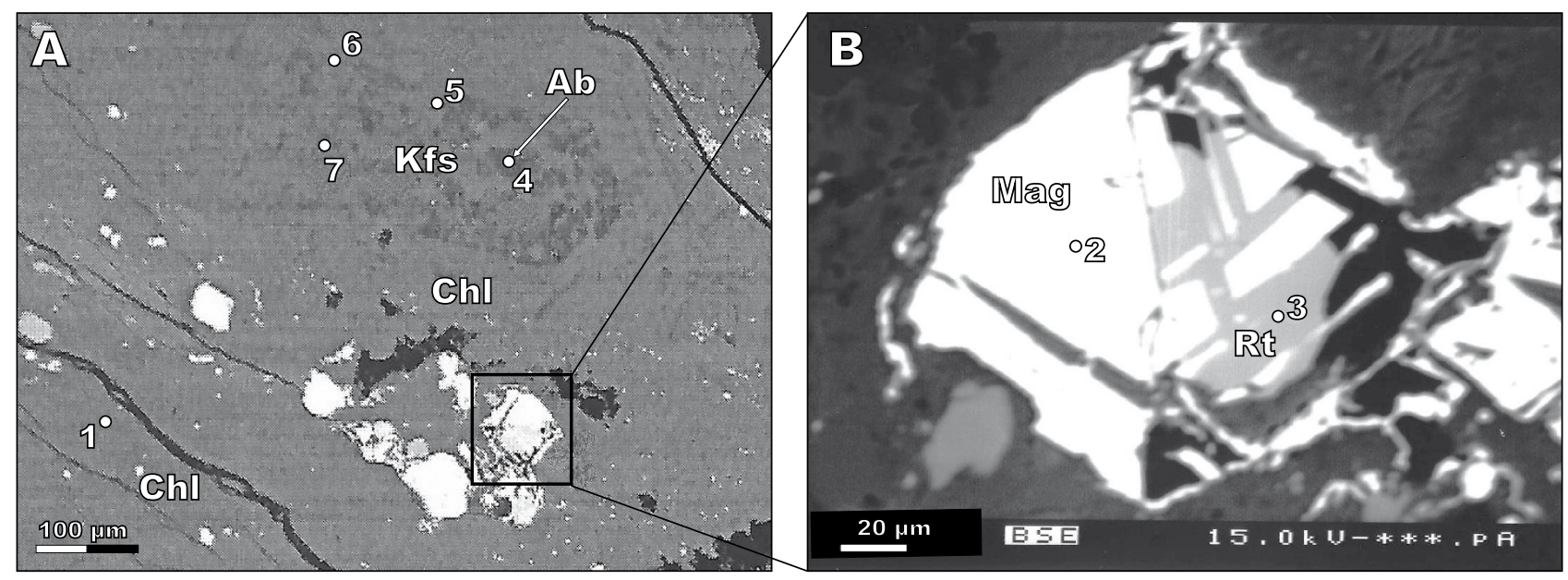

FIGURE 6. A-B) Back-scattered electron image of porfiric basaltic lava from the Mt. Kuna Gora. Mineral abbreviations after Kretz (1983): Ab= Albite, $\mathrm{Chl}=$ Chlorite, $\mathrm{Kfs}=\mathrm{K}$-feldspar, Mag= Magnetite, $\mathrm{Rt}=$ Rutile. 


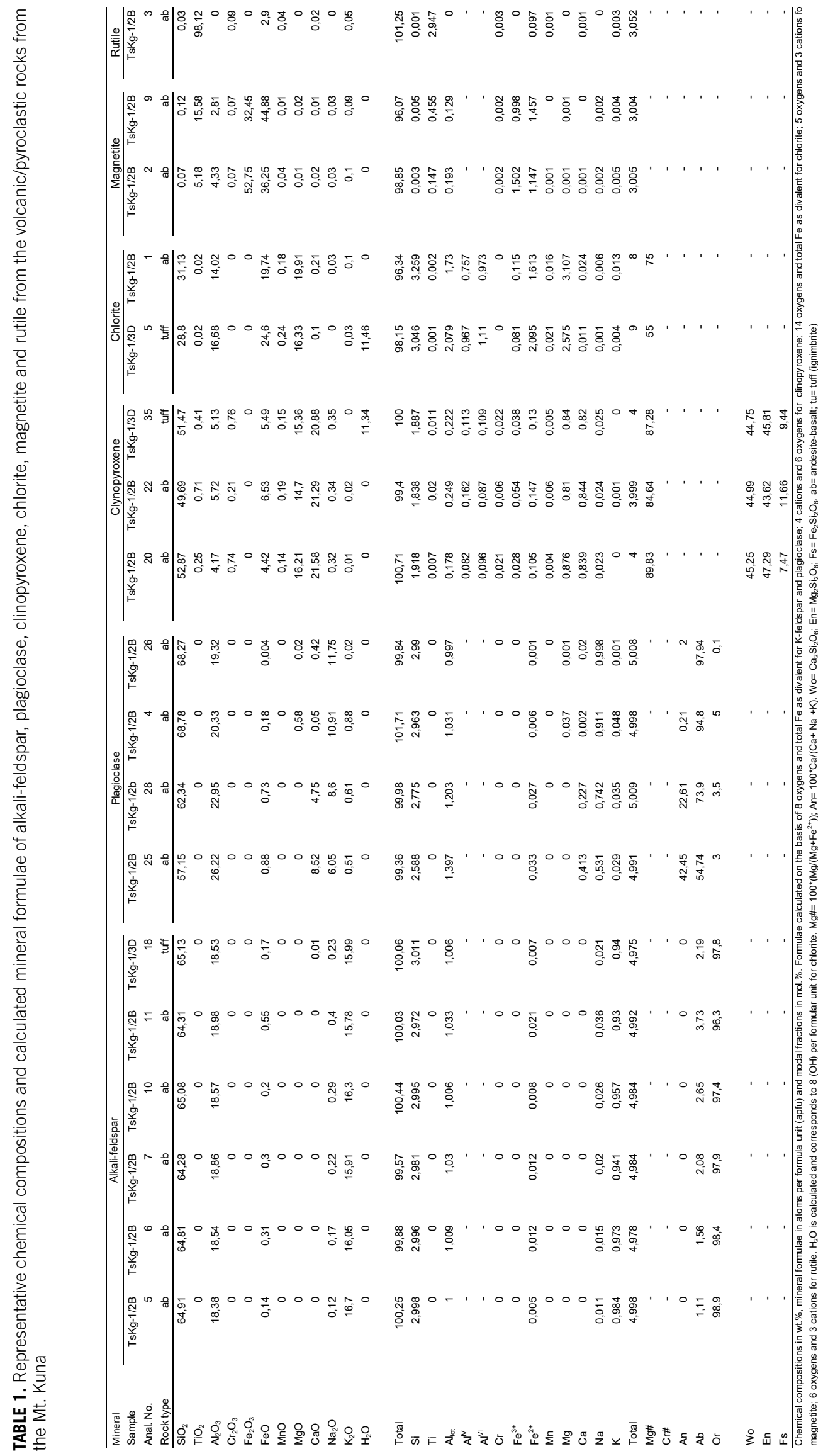


immobile. In the total alkali silica classification diagram the normalized values of analyzed rocks are plotted in the field of tephri-phonolites and trachyandesites (Fig. 7A). Owing to secondary alterations that are held responsible for somewhat elevated concentrations of $\mathrm{K}$, it has been utilized the classification scheme based on high-field element content. In the classification diagram $\mathrm{Nb} / \mathrm{Y}$ vs. $\mathrm{Zr} / \mathrm{TiO}_{2}$ x 0.0001 (Winchester and Floyd, 1977), analyzed rocks are plotted in the transition field of sub-alkaline basalts and andesites (andesite-basalts; Fig. 7B), which is typical of lavas formed formed in an island arc environment and along orogenic continental margins (e.g. Hall, 1996). High-K content coupled with very low $\mathrm{Na}_{2} \mathrm{O} / \mathrm{K}_{2} \mathrm{O}(<0.1)$, high values of $\mathrm{Ce} / \mathrm{Yb}(9.81-15.05)$ and $\mathrm{Ta} / \mathrm{Yb}(0.11-0.13)$ indicate high-K calc-alkaline affinity (Fig. 7C). The lavas show an evolved geochemical character and are moderately fractionated in terms of $\mathrm{Mg \#}$ and $\mathrm{Ni}$ content (59.4-64.4 and 11-19ppm, respectively). An overall uniform content of other compatible trace elements (e.g. Sc, Co, Sr, V; Table 2), with the exception of $\mathrm{Cr}$ whose concentrations are rather low $(<5 \mathrm{ppm})$, are in line with values typical of mafic lavas (e.g. Hall, 1996; Wilson, 1989). The moderately high content of $\mathrm{Zr}$ (115-136ppm) is due to the presence of accessory zircon and apatite.

All rocks show significant LILE $(\mathrm{Cs}, \mathrm{Rb}, \mathrm{K})$ and Th enrichment ranging from 38 to 133 times relative to $\mathrm{N}-\mathrm{MORB}$, and a nearly flat pattern for more immobile elements $(\mathrm{Zr}$ to $\mathrm{Lu})$, which ranges from 0.9 to 1.8 times relative to N-MORB (Fig. 8A). The content of HFSEs corresponds to those of orogenic andesites (e.g. Gill, 1981). Nevertheless, all rocks show significantly pronounced negative anomalies of $\mathrm{Nb}-\mathrm{Ta}$ relative to $\mathrm{La}\left[(\mathrm{Nb} / \mathrm{La})_{\mathrm{N}}=\right.$ 0.32-0.52], as well as of $\mathrm{Sr}$ and Ti typical of subductionrelated magmas (e.g. Hofmann, 1997; Pearce et al., 1984). The Mt. Kuna Gora effusive and pyroclastic rocks are also characterized by the weak positive $\mathrm{Pb}$ spikes relative to $\mathrm{Ce}$ $\left[(\mathrm{Pb} / \mathrm{Ce})_{\mathrm{N}}=1.14-1.18\right]$.

The samples define a monotonous trend in a narrow concentration span, which suggests a constant composition of fractionated phases (Fig. 8B). The normalized REE patterns show moderate enrichment of Light Rare Earth Elements (LREE) over Heavy Rare Earth Elements (HREE) $\left[(\mathrm{La} / \mathrm{Lu})_{\mathrm{CN}}=2.69-4.42\right]$ at 23-50 times chondrite relative concentrations. All samples show flat HREE profiles [ $(\mathrm{Tb} /$ $\left.\mathrm{Lu})_{\mathrm{CN}}=1.02-1.19\right]$ at 11-14 times relative to chondrite (Fig. $8 \mathrm{~B})$. The slight negative Eu anomaly $\left(\mathrm{Eu} / \mathrm{Eu}^{*}=0.81-0.88\right)$ in the analyzed rocks is typical of fractionation and removal of feldspar in more evolved rock types (e.g. Sun and Nesbitt, 1978; Wilson et al., 1995).

The values of ${ }^{143} \mathrm{Nd} /{ }^{144} \mathrm{Nd}$ of two representative samples are very consistent, ranging from 0.512652 to 0.512702 whilst ${ }^{87} \mathrm{Sr} /{ }^{86} \mathrm{Sr}$ shows a spread between 0.717118 and 0.718603
TABLE 2. Chemical compositions of volcanic/pyroclastic rocks from Mt. Kuna Gora

\begin{tabular}{|c|c|c|c|c|c|c|c|}
\hline Sample & TsKg-1 & TsKg-1/2B & TsKg-1/3D & TsKg-3 & TsKg-4 & TsKg-7 & TsKg-10 \\
\hline Rock type & $a b$ & $a b$ & tu & $a b$ & $a b$ & $a b$ & $a b$ \\
\hline$\overline{\mathrm{SiO}_{2}}$ & 50.29 & 49.50 & 48.40 & 49.22 & 50.95 & 49.65 & 50.36 \\
\hline $\mathrm{TiO}_{2}$ & 0.91 & 1.46 & 0.93 & 0.97 & 1.39 & 0.99 & 1.15 \\
\hline $\mathrm{Al}_{2} \mathrm{O}_{3}$ & 16.10 & 18.14 & 16.01 & 16.10 & 17.56 & 16.21 & 17.01 \\
\hline $\mathrm{Fe}_{2} \mathrm{O}_{3 \text { total }}$ & 8.31 & 8.86 & 8.22 & 8.28 & 8.76 & 8.35 & 8.92 \\
\hline $\mathrm{MnO}$ & 0.04 & 0.04 & 0.09 & 0.05 & 0.03 & 0.04 & 0.03 \\
\hline $\mathrm{MgO}$ & 6.36 & 7.00 & 6.81 & 6.01 & 7.09 & 6.12 & 6.56 \\
\hline $\mathrm{CaO}$ & 2.42 & 0.79 & 2.52 & 2.18 & 1.56 & 1.68 & 0.92 \\
\hline $\mathrm{Na}_{2} \mathrm{O}$ & 0.13 & 0.81 & 0.61 & 0.22 & 0.42 & 0.29 & 0.31 \\
\hline $\mathrm{K}_{2} \mathrm{O}$ & 9.58 & 8.36 & 9.15 & 9.62 & 8.21 & 9.35 & 8.65 \\
\hline $\mathrm{P}_{2} \mathrm{O}_{5}$ & 0.20 & 0.23 & 0.20 & 0.21 & 0.19 & 0.22 & 0.18 \\
\hline LOI & 5.40 & 5.20 & 6.90 & 7.01 & 3.84 & 6.77 & 5.52 \\
\hline Total & 99.83 & 99.82 & 99.82 & 99.87 & 100.00 & 99.67 & 99.61 \\
\hline Mg\# & 61.82 & 64.05 & 63.42 & 60.47 & 64.35 & 60.91 & 59.37 \\
\hline Cs & 0.9 & 1.3 & 0.9 & 0.8 & 1.5 & 0.8 & 1.1 \\
\hline $\mathrm{Rb}$ & 58 & 55 & 54 & 56 & 58 & 59 & 61 \\
\hline $\mathrm{Ba}$ & 116 & 200 & 161 & 108 & 169 & 129 & 152 \\
\hline Th & 5.4 & 7.3 & 4.8 & 4.6 & 6.8 & 4.9 & 5.9 \\
\hline Ta & 0.35 & 0.40 & 0.30 & 0.31 & 0.42 & 0.34 & 0.39 \\
\hline $\mathrm{Nb}$ & 5.5 & 6.4 & 4.8 & 4.3 & 6.8 & 4.9 & 5.3 \\
\hline $\mathrm{Sr}$ & 37 & 33 & 33 & 32 & 49 & 39 & 42 \\
\hline $\mathrm{Zr}$ & 128 & 123 & 118 & 115 & 136 & 130 & 128 \\
\hline $\mathrm{Hf}$ & 3.5 & 4.1 & 3.5 & 3.2 & 4.3 & 3.4 & 3.9 \\
\hline Y & 27 & 32 & 28 & 26 & 34 & 29 & 31 \\
\hline Sc & 23 & 18 & 21 & 24 & 17 & 22 & 19 \\
\hline V & 223 & 197 & 212 & 230 & 199 & 221 & 205 \\
\hline $\mathrm{Cr}$ & 41 & 27 & 34 & 44 & 24 & 38 & 31 \\
\hline $\mathrm{Ni}$ & 18 & 12 & 19 & 19 & 11 & 16 & 14 \\
\hline $\mathrm{Pb}$ & 2.3 & 2.3 & 1.9 & 2.0 & 1.9 & 2.1 & 1.8 \\
\hline Co & 23 & 20 & 24 & 25 & 19 & 26 & 21 \\
\hline $\mathrm{Zn}$ & 78 & 89 & 72 & 70 & 88 & 72 & 79 \\
\hline La & 18.30 & 13.20 & 16.10 & 13.10 & 18.50 & 15.80 & 16.30 \\
\hline $\mathrm{Ce}$ & 41.10 & 31.90 & 37.70 & 31.60 & 41.50 & 36.10 & 38.20 \\
\hline $\operatorname{Pr}$ & 5.03 & 3.95 & 4.67 & 3.92 & 51.40 & 4.33 & 5.02 \\
\hline $\mathrm{Nd}$ & 21.10 & 16.50 & 19.50 & 16.40 & 21.60 & 18.10 & 19.40 \\
\hline Sm & 4.65 & 3.79 & 4.45 & 3.96 & 4.72 & 4.51 & 4.61 \\
\hline $\mathrm{Eu}$ & 1.24 & 1.16 & 1.29 & 1.19 & 1.32 & 1.28 & 1.24 \\
\hline Eu & 4.59 & 4.31 & 4.59 & 4.29 & 4.72 & 4.49 & 4.58 \\
\hline $\mathrm{Tb}$ & 0.77 & 0.79 & 0.77 & 0.76 & 0.82 & 0.77 & 0.79 \\
\hline Dy & 4.37 & 5.19 & 4.65 & 4.28 & 5.31 & 4.39 & 4.72 \\
\hline $\mathrm{Ho}$ & 0.95 & 1.12 & 0.97 & 0.91 & 1.21 & 0.98 & 1.02 \\
\hline $\mathrm{Er}$ & 2.82 & 3.43 & 2.83 & 2.80 & 3.46 & 2.84 & 2.94 \\
\hline $\mathrm{Tm}$ & 0.43 & 0.51 & 0.43 & 0.41 & 0.52 & 0.45 & 0.46 \\
\hline $\mathrm{Yb}$ & 2.73 & 3.25 & 2.83 & 2.68 & 3.43 & 2.83 & 3.08 \\
\hline Lu & 0.43 & 0.51 & 0.44 & 0.42 & 0.53 & 0.44 & 0.48 \\
\hline
\end{tabular}

$\mathrm{Mg} \#=100^{*} \mathrm{molar}\left(\mathrm{MgO} /\left(\mathrm{MgO}+\mathrm{FeO}_{\text {total }}\right)\right)$. ab = andesite-basalt; tu = tuff (ignimbrite?

(Table 3). The initial $\varepsilon N d$ and initial isotopic ratios of $\mathrm{Sr}$ are calculated for $241 \mathrm{Ma}$, the crystallization age of analyzed andesite-basalts based on the K-Ar alkali-feldspar dating (see below). The initial $\varepsilon_{\mathrm{Nd}}$ varies between $+2.08( \pm 0.49)$ and $+2.88( \pm 0.56)$ whilst the initial ${ }^{87} \mathrm{Sr} /{ }^{86} \mathrm{Sr}$ varies from 0.702349 $( \pm 0.002)$ to $0.702693( \pm 0.002)$. Deuteric mobility of $\mathrm{Sr}$ and $\mathrm{Rb}$ could have led to overestimation of the original concentrations of these elements in the magma. Strontium isotopic data is therefore considered in the sense of an orientation value only. With this in mind, the ${ }^{143} \mathrm{Nd} /{ }^{144} \mathrm{Nd}$ vs. ${ }^{87} \mathrm{Sr} /{ }^{86} \mathrm{Sr}_{(\mathrm{t})}$ diagram may indicate an interaction/mixing of source regions (Fig. 9A). The complexity of the source areas and their related melts that gave rise to the effusive rocks of Mt. Kuna Gora is further 
adumbrated in the $\varepsilon_{\mathrm{Nd}(\mathrm{t})} \mathrm{vs} .{ }^{147} \mathrm{Sm} /{ }^{144} \mathrm{Nd}$ diagram, plotting in the transition zone between Ocean Island Basalts (OIB), Subducted Juvenile Material (SJM), and Subducted Continental Material (SCM) (Fig. 9B). The low initial ${ }^{143} \mathrm{Nd} /{ }^{144} \mathrm{Nd}$ and $\varepsilon_{\mathrm{Nd}(\mathrm{t})}$ values above bulk silicate earth may suggest a low degree of crustal contamination (Fig. 9A).

\section{K/Ar DATING}

The K-Ar alkali-feldspar age of effusive and pyroclastic

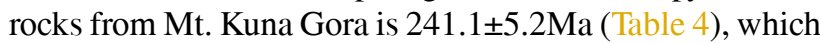

corresponds to the Middle Triassic epoch (Late AnisianEarly Ladinian, Ogg et al., 2016).

\section{DISCUSSION}

The Middle Triassic volcanism of NW Croatia is represented by submarine flows of basaltic to rhyolitic lavas and explosive eruptions of pyroclastic material (e.g. Goričan et al., 2005; Šimunić, 1992; Slovenec et al., 2020; and references therein). Previous stratigraphic studies identified two volcanic events. The first one occurred
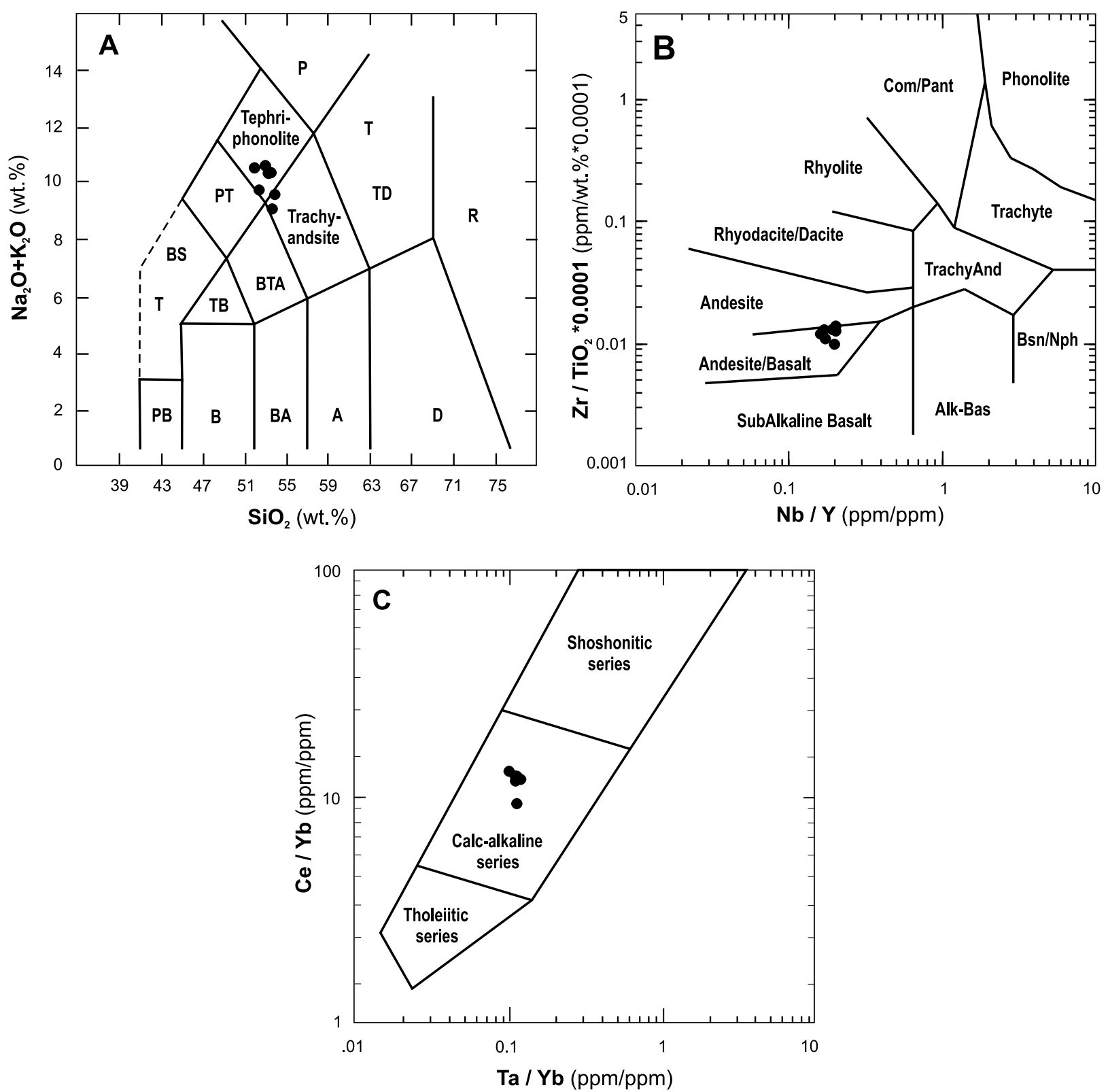

FIGURE 7. Classification diagrams of effusive and pyroclastic rocks from Mt. Kuna Gora. A) Total Alkali Silica classification diagram (Le Bas et al., 1986). B) Nb/Y-Zr/TiO ${ }^{*} 10^{-4}$ classification diagram (Winchester and Floyd, 1977). C) Ce/Yb-Ta/Yb discrimination diagram (Pearce, 1982). 

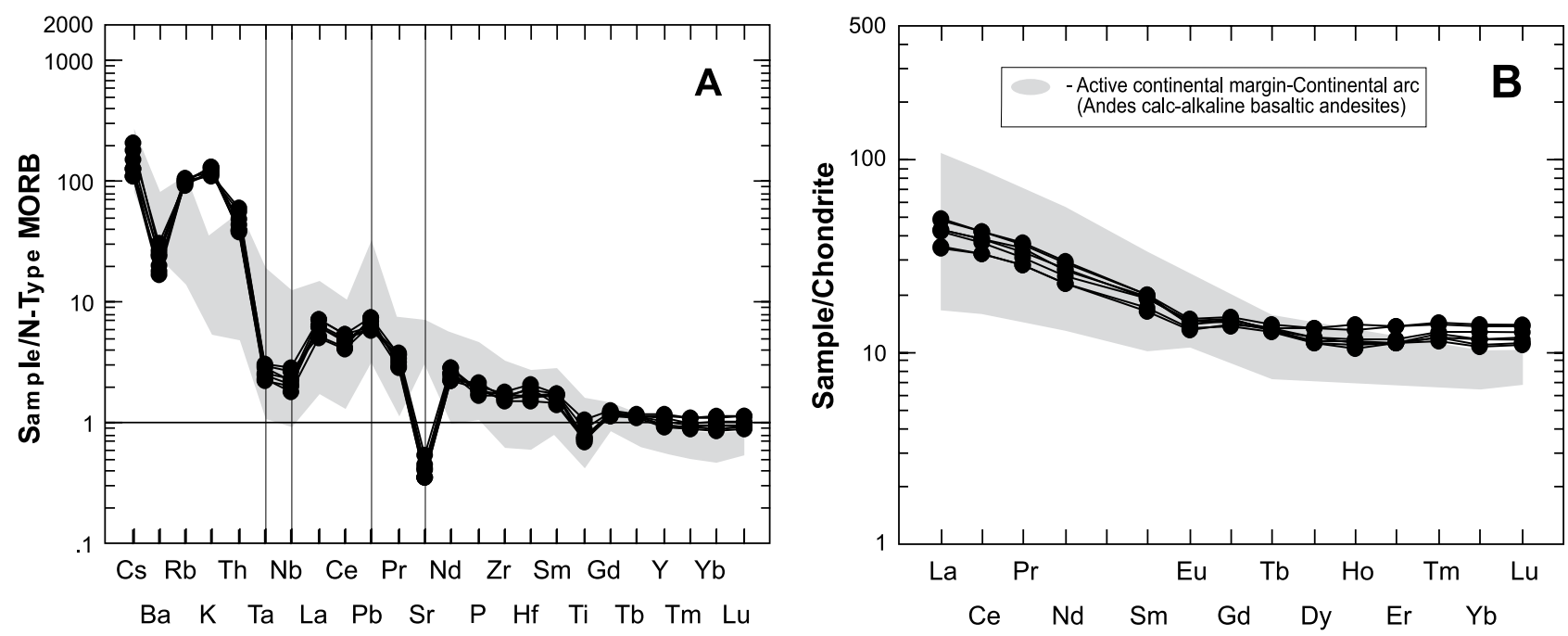

FIGURE 8. A) N-MORB-normalised multielement and B) REE patterns of the effusive and pyroclastic rocks from the Mt. Kuna Gora. Normalisation values are from Sun and McDonough (1989). Fields for Active continental margin-Continental arc calc-alkaline basaltic andesites in the Andes (Wilson, 1989) are plotted for correlation constraints.

during the Middle Anisian, when effusive rocks and tuffs formed. The tuffs are found interbedded with fine-grained clastic rocks and cherts. The second event took place in the Middle Ladinian and was characterized by massive lava flows and deposition of pyroclastic material (e.g. Šimunić, 1992; Šimunić and Šimunić, 1997; and references therein).

Published stratigraphic research does not provide the age and/or the environment of the volcanic activity during the Middle Triassic in NW Croatia. The research results presented in this paper based on mineralogical, petrological, geochemical and isotopic data allow new petrogenetic considerations about the origin and geotectonic environment of effusive and pyroclastic rocks of Kuna Gora Mt. and contribute to the understanding and reconstruction of events related to Middle Triassic volcanism.

\section{Petrogenesis}

The interstratification of pyroclastic and effusive rocks of Mt. Kuna Gora, their similar structure and analogue chemistry are in favor of contemporaneous lava flows and deposition of explosive material from pyroclastic flows. This calls for a common magma source(s), which was likely situated proximal to the sampling location, as suggested by the myriad of pristine euhedral and subhedral primary minerals.
The dominance of alkali-feldspar ( 45vol.\%), that crystallizes after the plagioclase and clinopyroxene, may be indicative of restrained and selective crystallization at a greater depths. The crystallization was followed by a rapid magma uplift, and quick and abundant crystallization of low-temperature felsic phases in the shallow crust. Such a scenario calls for a low magma differentiation, which is supported by low abundance of $\mathrm{SiO}_{2}(<51 \mathrm{wt} . \%)$ and uniform chemical composition of basaltic lavas and their pyroclastic (tuffaceous) manifestations.

The origin of analyzed rocks of Mt. Kuna Gora is complex. It can be inferred from the range of discrimination ratios of trace elements and the $\mathrm{Nd}$ isotopic data. The formation of these rocks implies either a contamination of a subduction-generated magma by lithospheric mantle melts or an enrichment of the mantle sources by subductionrelated crustal melts. Low $\mathrm{Ba} / \mathrm{Th}$ and $\mathrm{Sm} / \mathrm{La}$ coupled with high $\mathrm{Th} / \mathrm{La}$ and $(\mathrm{La} / \mathrm{Sm})_{\mathrm{N}}$ (Fig. 10) suggest an important role of subduction-related melts likely derived from crustal material. In this sense, melting of the down going slab can be assumed, while the usual fluid-saturated melting of the mantle wedge above the subducting slab is significantly subordinate. Positive values of initial $\varepsilon_{\mathrm{Nd}(\mathrm{t})}$ (up to 2.88) and low values of ${ }^{147} \mathrm{Sm} /{ }^{144} \mathrm{Nd}$ (up to 0.143662 ; Table 3) of analyzed effusive and pyroclastic rocks are also in line with

TABLE 3. Nd and Sr isotope data of volcanic rocks from Mt. Kuna Gora

\begin{tabular}{|c|c|c|c|c|c|c|c|c|c|c|}
\hline Sample & $\mathrm{Sm} / \mathrm{Nd}$ & ${ }^{147} \mathrm{Sm} /{ }^{144} \mathrm{Nd}$ & ${ }^{143} \mathrm{Nd} /{ }^{144} \mathrm{Nd}$ & ${ }^{143} \mathrm{Nd} /{ }^{144} \mathrm{Nd}_{(t)}$ & $\varepsilon_{\mathrm{Na}(t)}{ }^{a}$ & $\mathrm{Rb} / \mathrm{Sr}$ & ${ }^{87} \mathrm{Rb} /{ }^{86} \mathrm{Sr}$ & ${ }^{87} \mathrm{Sr} /{ }^{86} \mathrm{Sr}$ & ${ }^{87} \mathrm{Sr}^{86} \mathrm{Sr}_{(t)}{ }^{b}$ & Time $(\mathrm{t})^{*}$ \\
\hline TsKg-1/2B & $0.22821(0.11)$ & $0.137970(0.007)$ & $0.512652\left(8^{\star} 10^{-6}\right)$ & $0.512434\left(3^{*} 10^{-5}\right)$ & $+2.08(0.49)$ & $1.63636(0.08)$ & $4.741336(0.47)$ & $0.718603\left(11^{\star} 10^{-6}\right)$ & $0.702349(0.002)$ & $241 \pm 10.4 \mathrm{Ma}$ \\
\hline TsKg-10 & $0.23763(0.24)$ & $0.143661(0.007)$ & $0.512702\left(5^{\star} 10^{-6}\right)$ & $0.512475\left(3^{\star} 10^{-5}\right)$ & $+2.88(0.56)$ & $1.45238(0.07)$ & $4.207675(0.42)$ & $0.717118\left(10^{*} 10^{-6}\right)$ & $0.702693(0.002)$ & $241 \pm 10.4 \mathrm{Ma}$ \\
\hline
\end{tabular}



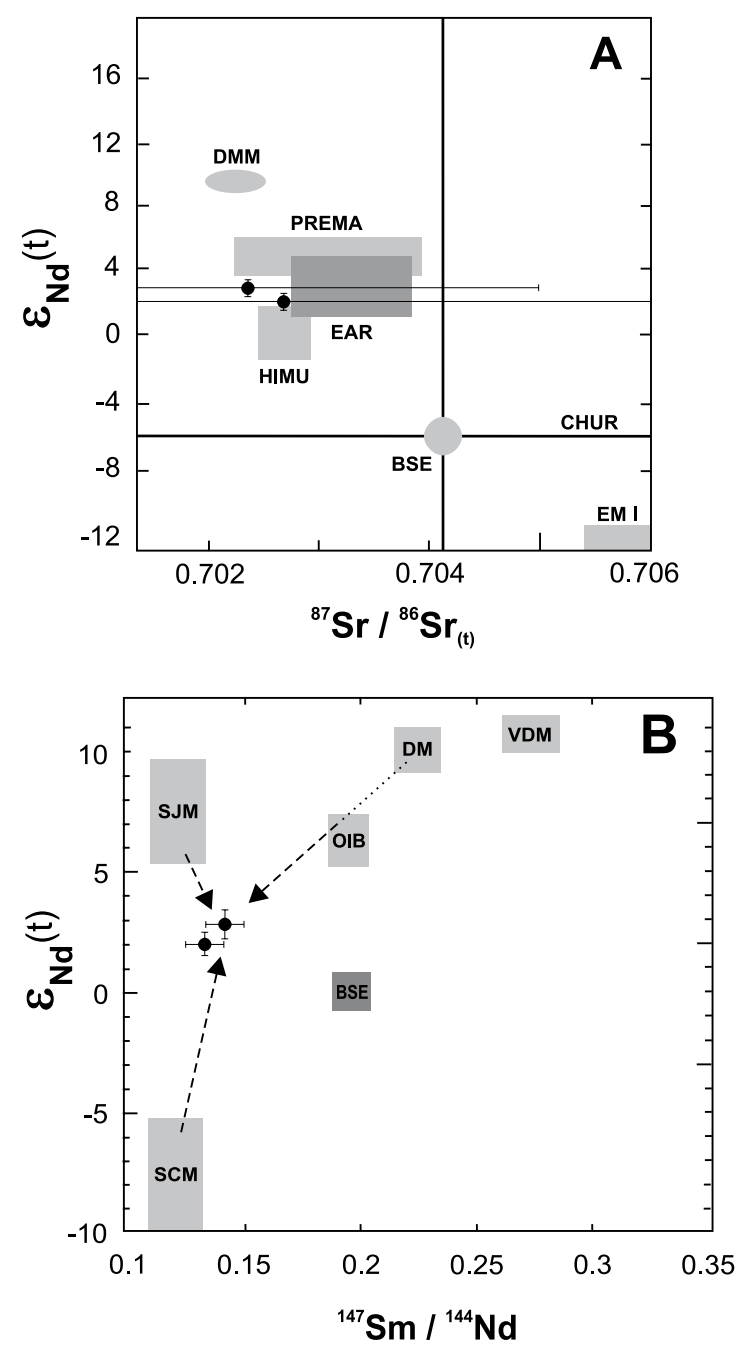

FIGURE 9. A) Initial (241Ma) ${ }^{87} \mathrm{Sr} / 86 \mathrm{Sr}-143 \mathrm{Nd} /{ }^{144} \mathrm{Nd}$ isotope ratios diagram for the effusive and pyroclastic rocks from Mt. Kuna Gora. Main mantle reservoirs (Hart and Zindler, 1989; Zindler and Hart, 1996; Workman and Hart, 2005). BSE= Bulk Silicate Earth, CHUR= Chondritic Uniform Reservoir, DMM= Depleted MORB Mantle, EAR= European Astenospheric Reservoir, EM I= Enriched Mantle, HIMU= mantle with high U/Pb ratio; PREMA = frequently observed PREvalent MAntle composition. B) ${ }^{147} \mathrm{Sm} /{ }^{144} \mathrm{Nd}-\varepsilon_{\mathrm{Nd}(t)}$ isotope ratios diagram of effusive and pyroclastic rocks from Mt. Kuna Gora. Hypothetical mantle sources: DM= Depleted Mantle (not refractory), VDM= Very Depleted Mantle (refractory), SJM= Subducted Juvenile Material (subducted oceanic crust; slab with little pelagic sediment), SCM= Subducted Continental Material and BE= Bulk Earth. The observed compositions and hypothetical endmembers sources calculated for the Middle Triassic following Swinden et al. (1990).

the input of subducted slab melts. This presumes a source largely built of subducted juvenile material whose origin was likely linked to the subducted Paleotethys oceanic crust (Fig. 9B). This conforms with the content of $\mathrm{Nd}$ (16-21ppm), which for juvenile mantle-derived magmas in volcanic regimes varies between 10 and 20ppm (Taylor and McLennan, 1995; White and Patchett, 1984). Yet, the sample projections in $\varepsilon_{\mathrm{Nd}(\mathrm{t})}$ vs. ${ }^{147} \mathrm{Sm} /{ }^{144} \mathrm{Nd}$ diagram (Fig. 9B) reveal a more complex magma composition that came into being through the partial melting and mixing of three source components: i) a LREE-enriched fertile arc mantle, ii) long-term LREE-enriched subducted continental material and iii) depleted or OIB-like mantle with long-term LREEdepletion (Fig. 9B). However, moderately high Th/La (0.3$0.4), \mathrm{Th} / \mathrm{Yb}$ (1.69-2.25), $\mathrm{Th} / \mathrm{Ta}(14.4-16.2)$ and $\mathrm{La} / \mathrm{Nb}$ (2.06-3.35) along with barely positive $\mathrm{Pb}$ spikes (up to 1.2), which are all susceptible to crustal contamination, do not reveal significantly elevated degrees of contamination with a crustal component. Furthermore, a high Rb/Cs ratio (3873) indicates a moderately low sedimentary contribution (e.g. Hildreth and Moorbath, 1988). On the other hand, minor contamination by upper continental crust (Fig. 10B) may stem from: i) subduction-related crustal melts, i.e. recycled sediments, and/or ii) rapid and short-term magma uplift through tectonically weakened zones of continental crust (e.g. Bialas et al., 2010; Hildreth and Moorbath, 1988). Finally, the positive trend of $\varepsilon_{\mathrm{Nd}}$ Vs. ${ }^{147} \mathrm{Sm} /{ }^{144} \mathrm{Nd}$ may suggest that genesis of parental magmas included melting of a mixed fertile-depleted mantle source with minor input from the continental crust. Nevertheless, significantly lower ${ }^{147} \mathrm{Sm} /{ }^{144} \mathrm{Nd}$ in studied lavas of Mt. Kuna Gora compared with the values reported in the material from the depleted mantle calls for a small contribution from an older LREEenriched source (Fig. 9B). Considering all the above, the formation of parental magma by hybridization of mantlederived and crust-derived magmas, at or near the mantlecrust transition (in which the melting-assimilation-storagehomogenization MASH process occurs), is characteristic of areas above subduction zones, as well as those below long-lived intraplate volcanoes (Hildreth and Moorbath, 1988).

Various authors implemented different geochemical variables to infer the amounts of partial melts extracted from a residual mantle source. It is hypothesized that this source was enriched by subduction-related processes that led to the application of a petrogenetic model based on the amounts of incompatible and immobile trace elements such as Dy and Yb (e.g. Rollinson, 1993; Thirwall et al., 1994). The Dy/ Yb vs. Yb diagram (Fig. 11) thus outlines spinel and garnet peridotites as plausible mantle sources. Accordingly, basalt to andesite composition lavas of Mt. Kuna Gora might have been produced through $\sim 8$ to $12 \%$ partial melting (Fig. 11) of a shallow mantle source. In addition to partial melting, the genesis of analyzed rocks must have included fractional crystallization, which is indicated by moderate values of $\mathrm{MgO} / \mathrm{FeO}_{\text {tot }}(0.81-0.92)$ coupled with very low abundances of $\mathrm{Ni}$ and $\mathrm{Cr}$ (11-10ppm and 26-44ppm, respectively). Considering an early crystallization of magnetite, the process of fractional crystallization must have taken place under oxidized conditions.

In brief, it is possible to hypothesize that analyzed rocks of Mt. Kuna Gora were derived through the processes of i) 
TABLE 4. K-Ar alkali-feldspar ages of volcanic rocks from Mt. Kuna Gora

\begin{tabular}{lrrrrrr}
\hline Sample & Location & Rock type & $\mathrm{K}[\%]$ & ${ }^{40}$ Arrad/g (nl/g) & ${ }^{40}$ Ar Atm [\% ] & Age $(\mathrm{Ma} \pm 1 \sigma)$ \\
\hline TsKg-1 & 1 & andesite-basalt & 7.540 & 75.61 & 3.80 & $241.1 \pm 5.2$ \\
\hline Location number corresponds to the location in Figure 1C
\end{tabular}

partial melting of the subcontinental lithospheric mantle, ii) subducting slab melting and iii) minor melting of a shallow asthenospheric mantle. Such "hybrid" magmas are suggested to have formed through the mixing of calcalkaline melts that originated in a subduction-modified mantle domain while minor amounts of melts originated in a depleted sub-lithospheric or OIB-like mantle source.

\section{Tectonomagmatic significance}

Analyzed effusive and pyroclastic rocks of Mt. Kuna Gora, in the $\mathrm{Hf} / 3-\mathrm{Th}-\mathrm{Nb} / 16$ diagram, are plotted within the field, which is unique for calc-alkaline arc-related effusive and pyroclastic rocks, thus suggesting a subduction-related environment (Fig. 12A). The same conclusion may be drawn from the clinopyroxene phase chemistry (Fig. 13). Enrichment in LILE and LREE and negative anomalies of $\mathrm{Nb}$-Ta and Ti (Fig. 8), along with depletion in HFSE, are all characteristics of subduction-related magmas and suggests a strong subduction influence and retention of these elements in the slab (e.g. Arculus and Powel, 1986; Hawkesworth et al., 1993, 1997; Pearce, 1982, 1983). However, moderately high content of $\mathrm{Zr}$, Hf, $\mathrm{Ta}, \mathrm{Nb}$ and $\mathrm{Th}$ (Table 2), as well as an increasing trend of their N-MORB normalized concentrations (Fig. 8A), suggest that their source is more intercrustal than subduction-derived (Hildreth and Moorbath, 1988 and references therein). The high-K calc-alkaline character of these rocks and their characterization based on $\mathrm{Th} / \mathrm{Ta}$ vs. $\mathrm{Yb}, \mathrm{La} / \mathrm{Yb}$ vs. Sc/Ni and $\mathrm{Th} / \mathrm{Nb}$ vs. $\mathrm{La} / \mathrm{Yb}$ clearly support the formation of $\mathrm{Mt}$. Kuna Gora lavas and pyroclastics in an ensialic and mature volcanic arc setting developed in an active, Andean-type, continental margin environment (Fig. 12B-D).

\section{Geodynamic significance}

Current paleogeographic reconstructions of Middle Permian to Middle Triassic tectonics suggest that the western Tethys Ocean, that was a large embayment of Panthalassa, was a remnant of the Paleotethyan Ocean (e.g. Berra and Angiolini, 2014 and references therein). This ocean had subducted northwards beneath the Laurussian (south European) active margin (e.g. Şengör, 1984; Stampfli and Borel, 2002, 2004; Schmid et al., 2008; Stampfli et al., 2013). According to these authors, the subduction was related to the opening of a newly formed Neotethyan Ocean to the south and the migration of Cimmeria that rifted from Gondwana toward the northeast. The opening of the Neotethys Ocean changed the tectonic constellation which lead to the closing of the Paleotethys Ocean during
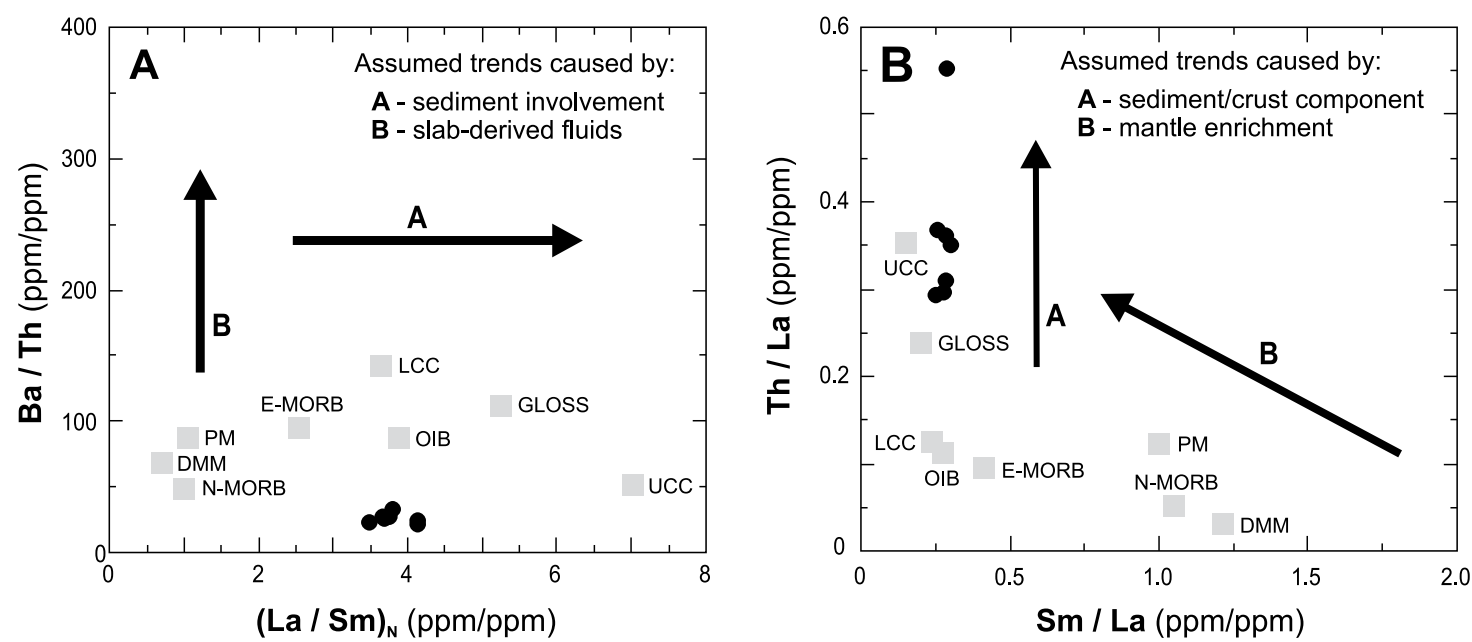

FIGURE 10. Discrimination diagrams for the effusive and pyroclastic rocks of Mt. Kuna Gora. A) Ba/Th-(La/Sm) diagram (after Eliot, 2004). B) Th/ La-Sm/La diagram (after Plank, 2005). Abbreviations: [N-MORB= Normal Mid-Ocean Ridge Basalts; E-MORB= Enriched MORB; OIB= Ocean Island Basalts; PM= Primitive Mantle (Sun and McDonough, 1989)]; [UCC= Upper Continental Crust; LCC= Lower Continental Crust (Taylor and McLenann, 1985)]; GLOSS= Global Subduction Sediment (Plank and Langmior, 1998); DMM= Depleted MORB Mantle (Workman and Hart, 2005). 


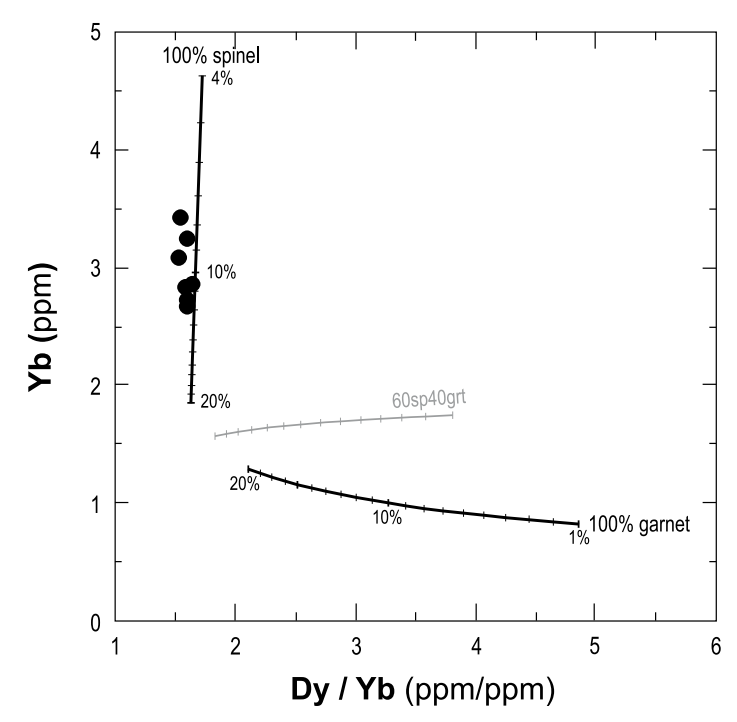

FIGURE 11. Yb-Dy/Yb diagram for the effusive and pyroclastic rocks of Mt. Kuna Gora. Partial melting curves are shown for the non-modal batch melting of spinel and garnet Iherzolite sources, starting from a Primitive Mantle (PM) material (McDonough and Frey, 1989). Mineral and melt modes for spinel and garnet-lherzolite source: $\mathrm{OI}_{0.58(0.10)}+$ $\mathrm{Opx}_{0.27(0.27)}+\mathrm{Cpx}_{0.12(0.50)}+\mathrm{Sp}_{0.03(0.13)}\left(\right.$ Kinzler, 1997) and $\mathrm{OI}_{0.60(0.05)}+$ $\mathrm{Opx}_{0.21(0.20)}+\mathrm{Cpx}_{0.08(0.30)}+\mathrm{Gt}_{0.12(0.45)}$ (Walter, 1998), respectively. Italic numbers in parentheses indicate the percentages of each mineral entering the liquid. Partition coefficients are from McKenzie and O’Nions (1991).

the Early Triassic and the subsequent formation of backarc basins (Stampfli et al., 2013). Although the western segment of the Paleotethys Ocean exhibited continuous magmatic activity during the Triassic period (e.g. Castorina et al., 2020; Kovács et al., 2011; Saccani et al., 2015; Zulauf et al., 2015, 2018; and references therein), the geotectonic characteristics of the magmatism as well as the exact geodynamic model are still somewhat controversial. These controversies relate to the genetic association of magmatism with active subduction processes or to riftingrelated processes (e.g. Lustrino et al., 2019; De Min et al., 2019; Neuebauer et al., 2019; and references therein). However, the subduction processes had an important impact on the composition of the magmas that formed the Triassic effusive and pyroclastic rocks in the western Paleotethys Ocean (internal and external Dinarides, Southern Alps, Trans-Danubian region and Bükk Mts.; Bébien et al., 1978; Castellarin et al., 1980, 1988; Harangi et al., 1996; Lustrino et al., 2019; Obenholzner, 1991; Slovenec et al., 2020; Smirčić et al., 2018; Trubelja et al., 2004; and references therein).

The geodynamic and isotopic data, and the mineral composition of the studied lavas and pyroclastic rocks (Figs. 8; 12; 13) along with their close spatial contact are all consistent with a subduction-related geotectonic model for their formation. This argues for the existence of an active, ensialic mature volcanic arc developed along southern active continental margins of Laurussia. The formation of an active continental arc is related to the northward subduction of the Paleotethyan lithosphere during the Late Anisian-Early Ladinian (Slovenec et al., 2020; Fig. 14). Geochemical signatures of this effusive to explosive volcanism were likely inherited from the Paleotethyan subduction slab. A high-K calc-alkaline arc-related volcanism (Fig. 12C-D) is characteristic of Andean-type active continental margins (Fig. 8). The origin of these magmas is very complex (involving mixing between several source components) and is marked by selective crystallization at maximum depths of about 45 to $49 \mathrm{~km}$, followed by a rapid magma uplift and abundant crystallization of felsic mineral phases (alkali feldspar) in the upper lithosphere. That is indicative of magma generation in a base of an ensialic volcanic arc. Possible minor to moderate sedimentary input revealed by analyzed effusive and pyroclastic rocks' geochemistry may be an indication of a large distances from the trench and consequently a greater-than-normal depth of the slab (e.g. Mazza et al., 2020).

During the Late Anisian the west Paleotethys Ocean was characterized by the uplift of a mantle dome that caused an adiabatic decompression and initial disintegration of the Adriatic-Dinaridic carbonate platform along a system of subparallel faults (e.g. Slovenec et al., 2020 and references therein). These processes enabled the proto back-arc rifting of the intra-continental lithosphere behind the peri-continental volcanic arc characterized by uncontaminated primitive (OIB-type) alkali lavas devoid of crustal contamination (e.g. Slovenec et al., 2010, 2011, and references therein; Fig. 14). This calls for a significant rollback and retreat of the subducted sinking slab (Slovenec et al., 2020), pointing to the final subduction stages of the Paleotethys plate (Stampfli et al., 2001; Ziegler and Stampfli, 2001). Under such circumstances the peripheral portions of the upwelling primitive OIB-like mantle dome (Fig. 14) might have slightly modified the composition of parental lavas in the subduction zone. A low degree of crustal contamination may result from a attenuation of the continental crust and/or rapid magma uplift through tectonically weakened zones of the crust. This model includes the demise of active subduction of the Paleotethys plate during Early-Middle Triassic time.

Although the model of active subduction has been favored in this study, the alternative geodynamic models that presumes Middle Triassic volcanism without contemporaneous active subduction should also be considered. The model proposed by Saccani et al. (2015) for the Albanide-Hellenide segment of the Tethys and the model of Lustrano et al. (2019) for the Triassic magmatism of the Southern Alps (Italy), suggest that calc-alkaline and shoshonitic rocks were generated by partial melting of the subduction-modified heterogeneous lithospheric (subcontinental) mantle. This subcontinental mantle had 


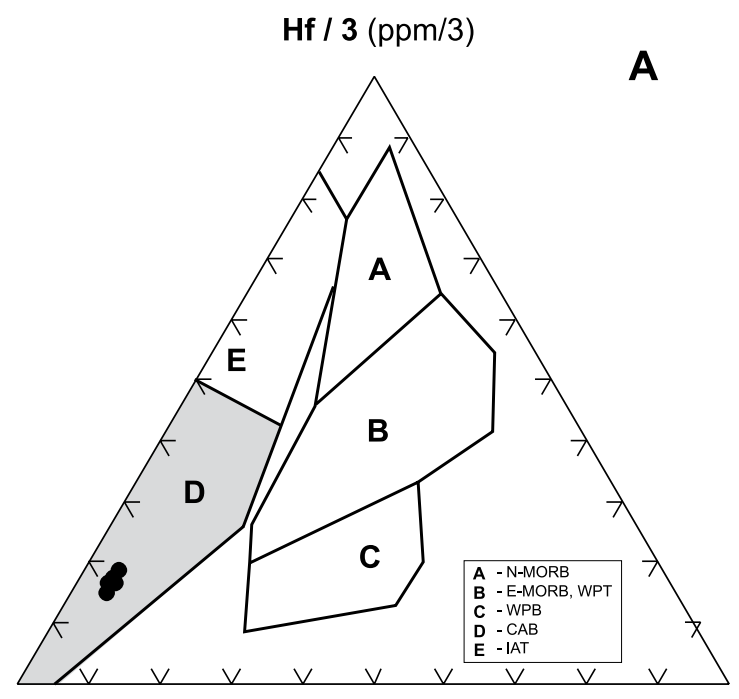

Th (ppm)

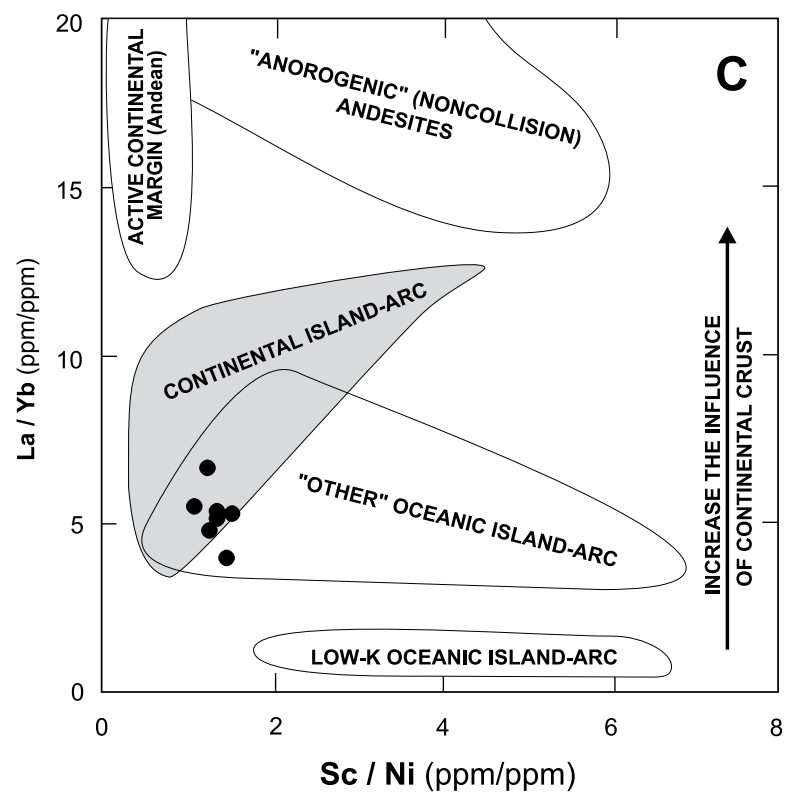

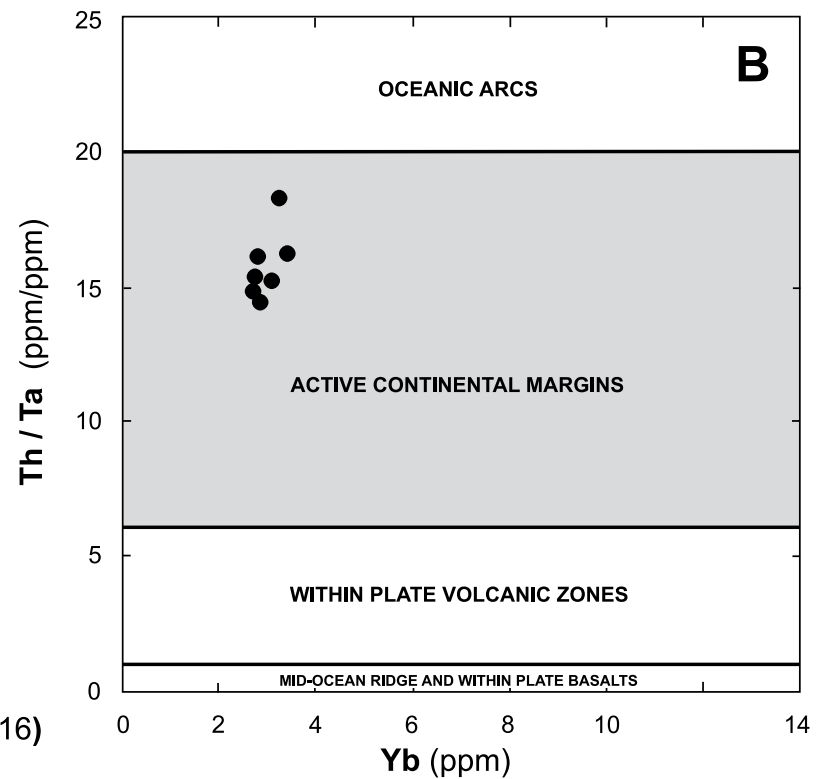

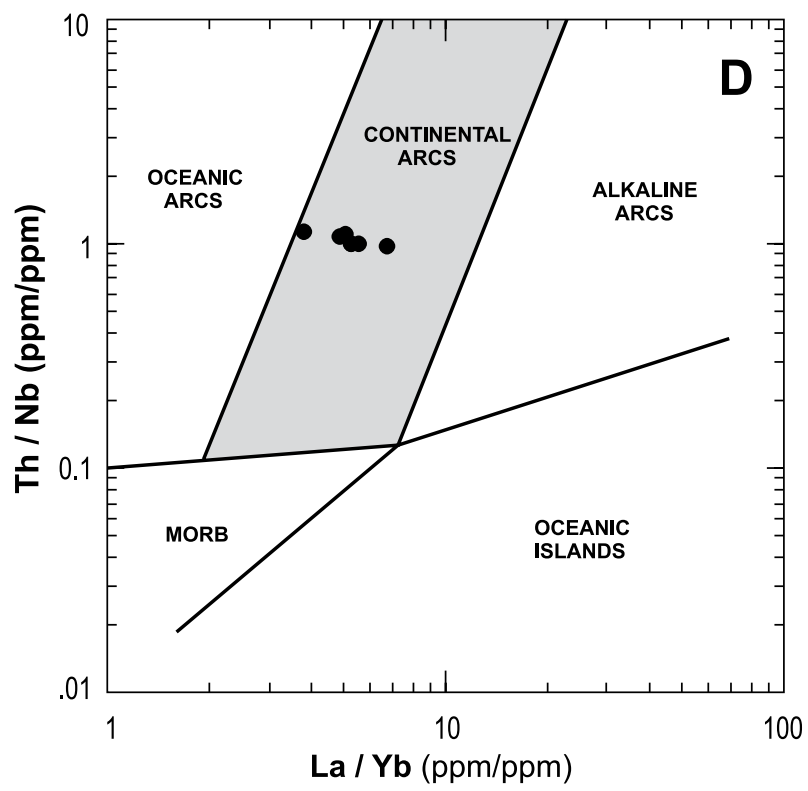

FIGURE 12. Discrimination diagrams for the effusive and pyroclastic rocks of Mt. Kuna Gora. A) Th-Nb/16-Hf/3 diagram (Wood, 1980). Abbreviations: $\mathrm{A}=$ Normal Mid-Ocean Ridge Basalts (N-MORB); $\mathrm{B}=$ Enriched MORB (E-MORB) and Within-Plate Tholeiites (WPT); $\mathrm{C}=$ Alkaline Within-Plate Basalts (AWPB); D= Calc-Alkali Basalts (CAB); $\mathrm{E}=$ Island-Arc Tholeiites (IAT). B) YbTh/Ta diagram for felsic and intermediate rocks (Gorton and Schandl, 2000). C) Sc/Ni-La/Yb diagram (Bailey, 1981). D) La/Yb-Th/Nb diagram (Hollocher et al., 2012).

been contaminated and/or metasomatized during earlier Hercynian subduction events in the Late Paleozoic when local geotherms were raised due to the passive upwelling of asthenospheric mantle along the rifted margins (Saccani et al., 2015).

\section{CONCLUSIONS}

High-K calc-alkaline lavas (andesite-basalts) and associated pyroclastic products (ash-flow tuffs) of analogue mineralogical and chemical composition from Mt. Kuna Gora (NW Croatia) suggests coeval lava- and pyroclastic flows before $241.1 \pm 5.2 \mathrm{Ma}$.

Petrographic data suggests the following crystallization sequence: spinel $\rightarrow$ clinopyroxene $\rightarrow$ plagioclase $\rightarrow$ alkalifeldspar $(\sim 45 \mathrm{vol} . \%) \pm$ Fe-Ti oxides.

The matrix of the effusive rocks consist of devitrified volcanic glass and microlites of plagioclase/albite. In the pyroclastics, the glassy matrix is altered into a mixture of 
fine-grained chlorite (formed between 124.9 and $253.8^{\circ} \mathrm{C}$ ) and white mica, further transformed into chlorite-smectite and mica-smectite during low-temperature diagenesis.

The crystallization of high-temperature mafic clinopyroxene in deeper segments of magmatic source $\left(\sim 1100^{\circ} \mathrm{C}\right)$ was limited and selective owing to the abrupt ascent of viscous andesite melts. However, the crystallization of low-temperature felsic mineral phase (alkali-feldspar; $\sim 680^{\circ} \mathrm{C}$ ) in upper lithospheric levels was rapid and abundant, resulting in poor magma differentiation.

Geochemical data as well as the isotopic composition of $\mathrm{Sr}$ and $\mathrm{Nd}$ indicate that the analyzed rocks had a complex origin, which included the contamination of a subduction-generated magma by melts of the lithospheric mantle. A lower level of crustal contamination represents the final phase of the proposed model for the formation of the studied "hybrid" magmas. A petrogenetic model for the formation of parental magmas accounts for the processes of partial melting and fractionation of subducted Paleotethys oceanic lithosphere and subcontinental lithospheric mantle. Analyzed high-K calc-alkaline rocks of Mt. Kuna Gora were derived by low degrees (8-12\%) of partial melting of a shallow

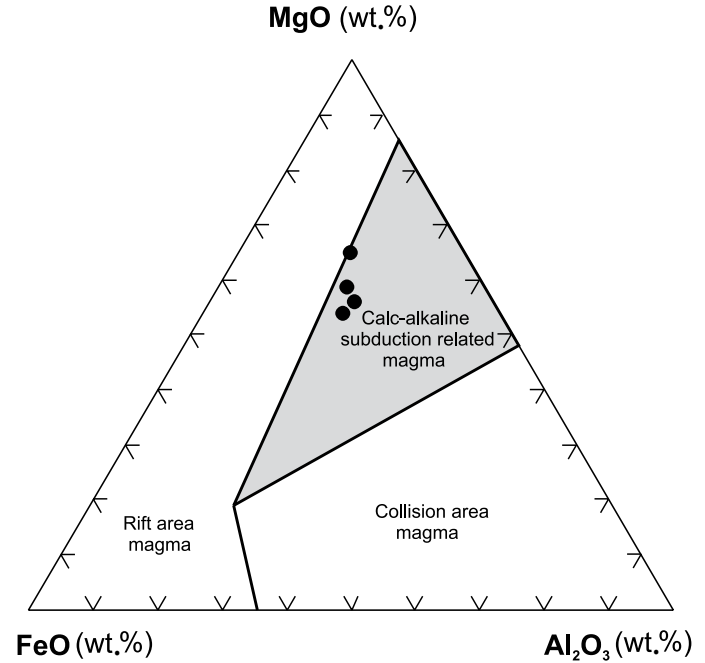

FIGURE 13. $\mathrm{FeO}-\mathrm{Al}_{2} \mathrm{O}_{3}-\mathrm{MgO}$ discriminant diagram (Le Bas, 1962) for pyroxene of effusive and pyroclastic rocks from Mt. Kuna Gora.

(spinel) mantle source region at maximal depths of $\sim 45$ $49 \mathrm{~km}$ and pressures $\leq 1.6 \mathrm{GPa}$.

The suggested geodynamic model for the formation of the effusive and pyroclastic rocks of Mt. Kuna Gora is
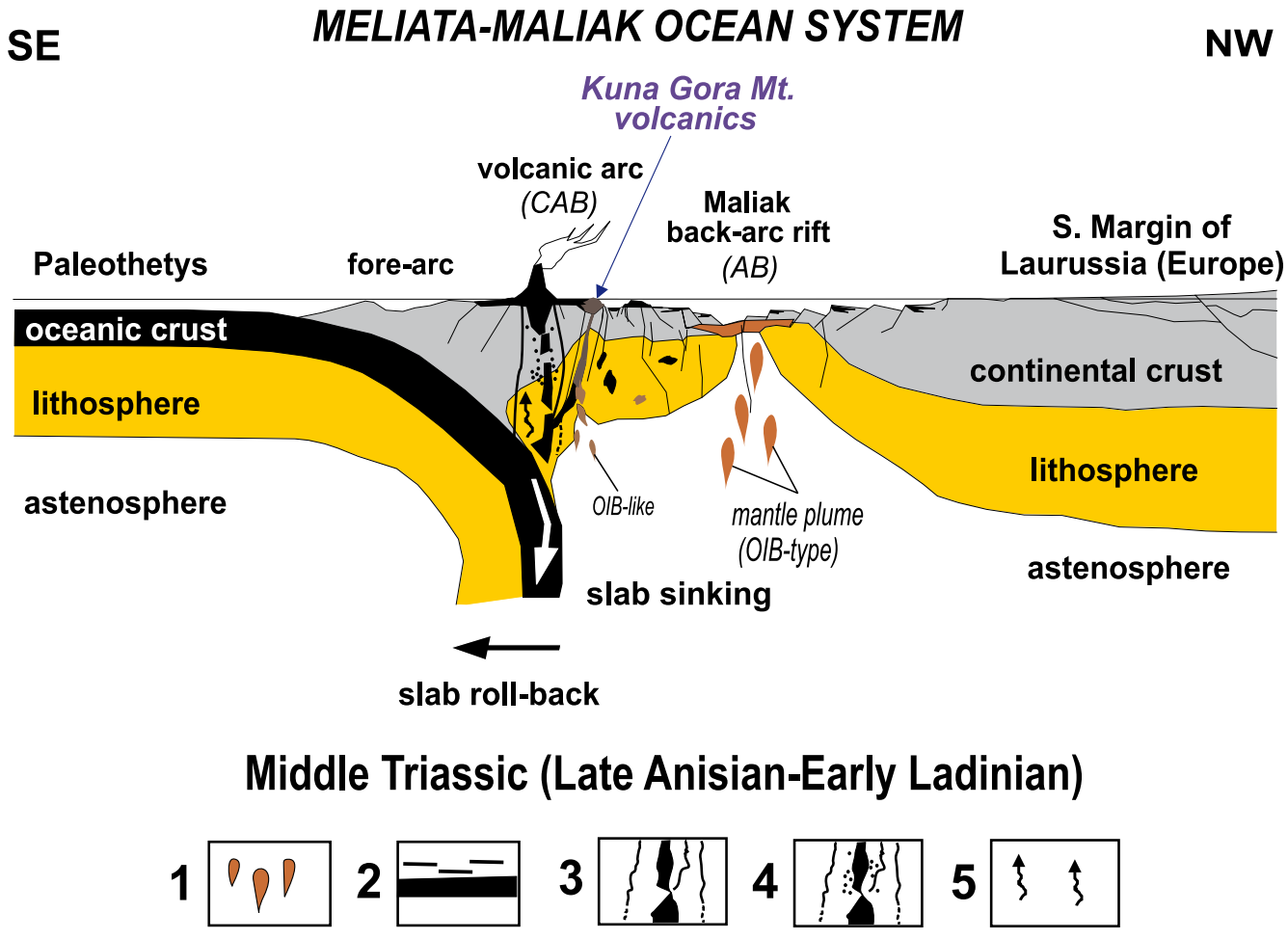

FIGURE 14. Geodynamic model of the interaction between the active continental margin magmatic ativity (subduction-related ensialic volcanic arc magmatism) and the roughly contemporaneous proto back-arc rifting in the Meliata-Maliak ocean system (slightly modified after Slovenec et al., 2020). Not to scale. $\mathrm{CAB}=$ Calc-Alkaline and shoshonitic Basalts/volcaniclastites, $\mathrm{AB}=\mathrm{Alkaline} B$ asalts, OIB= Ocean Island Basalts; $1=$ mantle diapirs, $2=$ oceanic crust topped by radiolarian cherts, $3=$ partially melted subducted oceanic lithosphere, $4=$ zone of partial melting and contamination by continental crust, $5=$ fluids from subducted slab. 
linked to the final phases of an active northward subduction of Paleotethys ocean lithosphere during early Mid-Triassic time. The model includes the existence of an active, ensialic mature volcanic arc developed at southern active continental margins of Laurussia along the northwestern branch of the Paleotethys Ocean.

\section{ACKNOWLEDGMENTS}

This work was supported by the Croatian Science Foundation under the project (IP-2019-04-3824). Additional support was received from the Croatian Ministry of Science, Education and Sport in the frame of the grant no. 181-1951126-1141 to Da. Slovenec. We thank Boško Lugović and Hans-Peter Meyer for microprobe analyses. We extend our appreciation to Bruno Mravlja and Giovanni Zanoni for their assistance with XRD measurements. Furthermore, valuable scientific discussions with Mirko Belak and Tonći Grgasović helped to improve an early version of the manuscript. Luka Badurina is acknowledged for his assistance with Monte Carlo simulation modelling. Critical comments and constructive reviews by two anonymous reviewers, as well as the editorial handling by Michael Ort and Laura Rincón, contributed significantly to the manuscript quality.

\section{REFERENCES}

Abbas, H., Michail, M., Cifelli, F., Mattei, M., Gianolla, P., Lustrino, M., Carminati, E., 2018. Emplacement modes of the Ladinian plutonic rocks of the Dolomites: Insights from anisotropy of magnetic susceptibility. Journal of Structural Geology, 113, 42-61.

Aljinović, D., Kolar-Jurkovšek, T., Jurkovšek, B., Hrvatović, H., 2010. Characteristics of some Middle Triassic volcaniclastic rocks in the External Dinarides (Croatia and Bosnia and Herzegovina). In: Horvat, M. (ed.). Abstract Book. 4st Croatian Geological Congress, Šibenik, Croatian Geological Survey, 14-15.

Aničić, B., Jureša, M., 1984. Basic geological map SFRJ 1:100,000. Rogatec sheet (in Croatian). Institut za geološka istraživanja Zagreb, Savezni geološki zavod Beograd.

Arculus, R.J., Powell, R., 1986. Source component mixing in the regions of arc magma generation. Journal of Geophysical Research, 91, 5913-5926.

Avanzinelli, R., Prytulak, J., Skora, S., Heumann, A., Koetsier, G., Elliott, T., 2012. Combined 238U-230Th and 235U-231Pa constraints on the transport of slab-derived material beneath the Mariana Islands. Geochimica Cosmochimica Acta, 95, 308-328.

Bailey, J.C., 1981. Geochemical criteria for a refined tectonic discrimination of orogenic andesites. Chemical Geology, 32, 139-154.

Bébien, J., Blanchet, R., Cadet, J.P., Charvet, J., Chorowitz, J., Lapierre, H., Rampnoux, J.P., 1978. Le volcanisme triasique des Dinarides en Yougoslavie: sa place dans l'évolution géotectonique péri-méditerrenéenne. Tectonophysics, 47, 159-176.

Beccaluva, L., Coltorti, M., Saccani, E., Siena, F, Zeda, O., 2005. Triassic magmatism and Jurassic ophiolites at the margins of the Adria Plate. In: Finetti, I.R. (ed.). Crop Project: Deep Seismic Exploration of the Central Mediterranean and Italy. Elsevier, 28, 607-622.

Berra, F., Angiolini, L., 2014. The evolution of the Tethys region throughout the Phanerozoic: A brief tectonic reconstruction. In: Marlow, L., Kendall, C., Yose, L. (eds.). Petroleum systems of the Tethyan region. American Association of Petroleum Ggeologists Memoir, 106, 1-27.

Bialas, R.W., Buck, W.R., Qin, R., 2010. How much magma is required to rift a continent? Earth and Planetary Science Letters, 292, 68-78.

Bianchini, G., Natali, C., Shibata, T., Yoshikawa, M., 2018. Basic dykes crosscutting the crystalline basement of Valsugana (Italy): new evidence of Early Triassic volcanism in the Southern Alps. Tectonics, 37, 2080-93.

Bonadiman, C., Coltorti, M., Siena, F, 1994. Petrogenesis and T-fO2 estimates of Mt. Monzoni complex (Central Dolomites, Southern Alps): a Triassic shoshonotic intrusion in a transcurrent geodynamic setting. European Journal of Mineralogy, 6, 943-966.

Bortolotti, V., Principi, G., 2005. Tethyan ophiolites and Pangea break-up. Island Arc, 14, 442-70.

Bortolotti, V., Chiari, M., Marroni, M., Pandolfi, L., Principi, G., Saccani, E., 2013. The geodynamic evolution of the ophiolites from Albania and Greece, Dinaric-Hellenic Belt: one, two, or more oceanic basins? International Journal of Earth Sciences, 102, 783-811.

Cameron, B.I., Walker, J.A., Carr, M.J., Patino, L.C., Matias, O., Feigenson, M.D., 2003. Flux versus decompression melting at stratovolcanoes in southeastern Guatemala. Journal of Volcanology and Geothermal Research, 119, 21-50.

Casetta, F., Coltorti, M., Marrocchino, E., 2018. Petrological evolution of the middle Triassic Predazzo intrusive complex, Italian Alps. International Geology Review, 60, 977-997.

Casetta, F., Ickert, R.B., Mark, D.F., Bonadiman, C., Giacomoni, P.P., Ntaflos, T., Coltorti, M., 2019. The alkaline lamprophyres of the Dolomitic Area (Southern Alps, Italy): markers of the Late Triassic change from orogenic-like to anorogenic magmatism. Journal of Petrology, 60, 1263-1298.

Cassinis, G., Cortesogno, L., Gaggero, L., Perotti, C.R., Buzzi, L., 2008. Permian to Triassic geodynamic and magmatic evolution of the Brescian Prealps (eastern Lombardy, Italy). Bollettino della Società Geologica Italiana, 127, 501-518.

Castellarin, A., Lucchini, F., Rossi, P.L., Simboli, G., Bosellini, A., Sommavilla, E., 1980. Middle Triassic magmatism in southern Alps II: a geodynamic model. Rivista Italiana di Paleontologia e Stratigrafia, 85, 3-4.

Castellarin, A., Lucchini, F, Rossi, P.L., Selli, L., Simboli, G., 1988. The Middle Triassic magmatic-tectonic arc developed in the southern Alps. Tectonophysics, 146, 79-89. 
Castorina, F., Magganas, A., Masi, U., Kyriakopoulos, K., 2020. Geochemical and Sr-Nd isotopic evidence for petrogenesis and geodynamic setting of Lower-Middle Triassic volcanogenic rocks from central Greece: Implications for the Neotethyan Pindos ocean. Mineralogy and Petrology, 114, 39-56.

Cathelineau, M., 1988. Cation site occupancy in chlorites and illites as a function of temperature. Clay Minerals, 23, 471-485.

Cox, K.G., Bell, J.D., Pankhurst, R.J., 1979. The Interpretation of Igneous Rocks. London, George Allen and Unwin, 450pp.

Crisci, C.M., Ferrara, G., Mazzuoli, R., Rossi, P.M., 1984. Geochemical and geochronological data on Triassic volcanism in the Southern Alps of Lombardy (Italy): genetic implications. Geologische Rundschau, 73, 279-292.

Csontos, L., Vörös, A., 2004. Mesozoic plate tectonic reconstruction of the Charpatian region. Palaeogeography Palaeoclimatology Palaeoecology, 210, 1-56.

Dana, J.D., Klein, C., Hurlbut, C.S., 1993. Manual of mineralogy. New York, Wiley, 532pp.

Deer, W.A., Howie, R.A., Zussman, J., 1992. An introduction to the rock-forming minerals. Longman Group Limited, 696pp

Elliott, T.R., Plank, T., Zindler, A., White, W., Bourdon, B., 1997. Element transport from slab to volcanic front at the Mariana arc. Journal of Geophysical Research, 102, 14991-15019.

Elliott, T.R., 2003. Tracers of the slab. In: Eiler, J. (ed.). Inside the subduction factory. Washington DC, Geophysical Monograph, American Geology Union, 138, 23-45.

Gill, J.B., 1981. Orogenic andesites and plate tectonics. BerlinHeidelberg-New York, Springer, 390pp.

Golub, Lj., Brajdić, V., 1968. Basalt from Žutica near Krapina (Croatian Zagorje) (in Croatian, with English abstract). Geološki vjesnik, 21, 249-254.

Golub, Lj., Brajdić, V., Šebečić, B., 1969. Eruptive and pyroclastic rocks from Mt. Strahinjščica (Croatan Zagorje) (in Croatian, with English abstract). Geološki vjesnik, 23, 205-217.

Golub, Lj., Brajdić, V., 1970. Eruptive and pyroclastic rocks from Vudelja and from the Bistrica brook on the northern slopes of Mt. Ivanščica (Hrvatsko Zagorje-Yugoslavia) (in Croatian, with English abstract). Zbornik radova Rudarsko-geološkonaftnog fakulteta (30. god. rada, 1939-1969), 123-127.

Goričan, Š., Halamić, J., Grgasović, T., Kolar-Jurkovšek, T., 2005. Stratigraphic evolution of Triassic arc-back arc system in northwestern Croatia. Bulletin de la Société Géologique de France, 176, 3-22.

Gorton, M.P., Shandl, E.S., 2000. From continents to island arcs: A geochemical index of tectonic setting for arc-related and within-plate felsic to intermediate volcanic rocks. Canadian Mineralogist, 38, 1065-1073.

Graciansky, P-C., Roberts, D.G., Tricart, P., 2011. The Western Alps, from Rift to Passive Margin to Orogenic Belt: An integrated geoscience overview. In: Shroder, J.F (ed.). Developments in Earth surface processes. Amsterdam, Elsevier, 391pp.

Grimes, C.B., Wooden, J.L., Cheadle, M.J., John, B.E., 2015. "Fingerprinting" tectono-magmatic provenance using trace elements in igneous zircon. Contribution to Mineralogy and Petrology, 170, 46.
Haas, J., Mioč, P., Pamić, J., Tomljenović, B., Árkai, P., BércziMakk, A., Koroknai, B., Kovács, S., R-Felgenhauer, E., 2000. Complex structural pattern of the Alpine-Dinaridic Pannonian triple junction. International Journal of Earth Sciences, 89, 377-389.

Haas, J., Kovács, S., 2001. The Dinaridic-Alpine connection-as seen from Hungary. Acta Geologica Hungarica, 44, 345-362.

Halamić, J., 1998. The lithostratigraphic characterisation of Jurassic and Cretaceous sediments with ophiolite of Mts. Medvednica, Kalnik and Ivanščica (in Croatian, with English abstract). PhD Thesis. University of Zagreb, Zagreb, 184pp.

Hall, A., 1996. Igneous Petrology. London, Longman, 551pp.

Harangi, Sz., Szabó, Cs., Józsa, S., Szoldán, Zs., Árva-Sós, E., Balla, M., Kubovics, I., 1996. Mesozoic igneous suites in Hungary: Implications for genesis and tectonic setting in the northwestern part of Tethys. International Geolological Review, 38, 336-360.

Hart, S., Zindler, A., 1989. Constraints on the nature and development of chemical heterogeneities in the mantle. In: Peltier, W.R. (ed.). Mantle Convection. New York, Gordon and Breach Science Publishers, 216-387.

Hawkesworth, C.J., Herft, J.M., Mcdermott, F, Ellam, R.M., 1991. Destructive margin magmatism and the contributions from the mantle wedge and subducted crust. Austrian Journal of Earth Sciences, 38, 577-594.

Hawkesworth, C.J., Gallagher, K., Hergt, J.M., Mcdermott, F, 1993. Trace element fractionation processes in the generation of island arc basalts. In: Cox, K.G., Mckenzie, D.P., White, R.S. (eds.). Melting and melt movement in the Earth. Philosophical Transactions of Royal Society London, Oxford University Press, A342, 179-191.

Hawkesworth, C., Turner, S., Gallagher, K., Hunter, A., Bradshaw, T., Rogers, N., 1995. Calc-alkaline magmatism, lithospheric thinning and extension in the Basin and Range. Journal of Geophysical Research, 100, 10271-10286.

Hawkesworth, C.J., Turner, S.P, Mcdermott, F, Peate, D.W., Van Calsteren, P., 1997. U-Th isotopes in arc magmas: implications for element transfer from the subducted crust. Science, 276, 551-555.

Hey, M.H., 1954. A new review of the chlorites. Mineralogical Magazine, 30, 277-292.

Hildreth, W., Moorbath, S., 1988. Crustal contributions to arc magmatism in the Andes of Central Chile. Contribution to Mineralogy and Petrology, 98, 455-489.

Hofmann, A.W., 1997. Mantle geochemistry: the message from oceanic volcanism. Nature, 385, 219-229.

Hollocher, K., Robinson, P., Walsh, E., Roberts, D., 2012. Geochemistry of amphibolite facies volcanics and gabbros of the Støren Nappe in extensions west and southwest of Trondheim, Western Gneiss Region, Norway: a key to correlations and paleotectonic settings. American Journal of Science, 312, 357-416.

Hooper, P.R., Bailey, D.G., McCarley Holder, G.A., 1995, Tertiary calc-alkaline magmatism associated with lithospheric 
extension in the Pacific Northwest. Journal of Geophysical Research, 100, 10303-10319.

Hövelmann, J., Putnis, A., Geisler, T., Schmidt, B.C., GollaSchindler, U., 2010. The replacement of plagioclase feldspars by albite: observations from hydrothermal experiments. Contribution to Mineralogy and Petrology, 159, 43-59.

Johnson, R.W., Mackenzie, D.E., Smith, I.E.M., 1978. Delayed partial melting of subduction-modified mantle in Papua New Guinea. Tectonophysics, 46, 197-216.

Jowet, E.C., 1991. Fitting Iron and Magnesium into the Hydrothermal Chlorite Geothermometer. Abstracts of the GAC/MAC/SEG Joint Annual Meeting (Toronto, May 27-29, 1991), 16, A62.

Kaur, P., Chaudhri, N., Hofmann, A.W., 2015. New evidence for two sharp replacement fronts during albitization of granitoids from northern Aravalli orogen, northwest India. International Geology Review, 57, 1660-1685.

Keller, J., 1982. Mediterranean Island arcs. In: Thorpe, R.S. (ed.). In Andesites, Orogenic Andesites and Related Rocks. New York, John Wiley and Sons, 308-325.

Kinzler, R.J., 1997. Melting of mantle peridotite at pressure approaching the spinel to garnet transition: application to mid-ocean ridge basalt petrogenesis. Journal of Geophysical Research, 102, 853-874.

Knežević, V., Jovanović, V., Memović, E., Resimović, K., 1998. Triassic magmatic rocks of Yugoslav Dinarides-in Serbia (in Serbian, with English abstract). XIII kongres geologa Jugoslavije, Herceg Novi, Zbornik radova, 3, 61-66.

Kovács, S., 1989. Major events of the tectono-sedimentary evolution of the north Hungarian Paleo-Mesozoic: History of the NW termination of the Late Paleozoic-Early Mesozoic Tethys. In: Segnör, A.M. (ed.). Tectonic evolution of the Tethyan region. London, Mathematic and Phisical Sciences, Klaver Academian Publications, Series C, 259, 93-108.

Kovács, S., 1992. Tethys "western ends" during the late Paleozoic and Triassic and their possible genetic relationships. Acta Geologica Hungarica, 35, 329-369.

Kovács, S., Sudar, M., Gr $\square$ dinaru, E., Gawlick, H-J., Karamata, S., Haas, J., Péró, C., Gaetani, M., Mello, J, Polák, M., Aljinović, D., Ogorelec, B., Kolar-Jurkovšek, T., Jurkovšek, B., Buser, S., 2011. Triassic Evolution of the Tectonostratigraphic Units of the Circum-Pannonian Region. Jahrbuch der Geologischen Bundesanstalt, 151, 199-280.

Kranidiotis, P., Maclean, W.H., 1987. Systematics of Chlorite Alteration at the Phelps Dodge Massive Sulfide Deposit, Matagami, Quebec. Economic Geology, 82, 1898-1911.

Kretz, R., 1983. Symbols for rock-forming minerals. American Mineralogist, 68, 277-279.

Le Bas, M.J., 1962. The role of aluminium in igneous clinopyroxene with relation to their parentage. American Journal of Science, 260, 267-288.

Le Bas, J.M., Le Maitre, R.V., Streckeisen, A., Zanettin, B., 1986. A chemical classification of volcanic rocks based on the total alkali-silica diagram. Journal of Petrology, 27, 745-75.

Lindsley, D.H., 1983. Pyroxene thermometry. American Mineralogist, 68, 477-493.
Lustrino, M., Duggen, S., Rosenberg, C.L., 2011. The centralwestern Mediterranean: anomalous igneous activity in an anomalous collisional tectonic setting. Earth Science Review, $104,1-40$.

Lustrino, M., Abbas, H., Agostini, S., Gaggiati, M., Carminati, E., Gianolla, P., 2019. Origin of Triassic magmatism of the Southern Alps (Italy): constraints from geochemistry and Sr$\mathrm{Nd}-\mathrm{Pb}$ isotopic ratios. Gondwana Research, 75, 218-238.

Marci, V., Šćavničar, S., Sijarić, G., 1982. Petrogenesis of the volcanic rocks of Ivanščica Mt. (River Željeznica) (in Croatian, with English summary). X kongres geologa Jugoslavije, Budva, Zbornik radova, 1, 329-335.

Marci, V., Ščavnićar, S., Sijarić, G., 1984. The new data about volcanic rocks of Ivanščica mountain (in Croatian, with English summary). Geološki Vjesnik, 37, 97-104.

Mazza, S.H., Stracke, A., Gill, J.B., Kimura, J-I., Kleine, T., 2020. Tracing dehydration and melting of the subducted slab with tungsten isotopes in arc lavas. Earth and Planetary Science Letters, 530, 115942.

McCann, T., 2008. The geology of Central Europe, vol. 2: Mesozoic and Cenozoic. London, The Geological Society, 1491pp.

McDonough, W.F, Frey, FA., 1989. REE in upper mantle rocks. In: Lipin, B., McKay, G.R. (eds.). Geochemistry and mineralogy of rare earth elements. Chelsea, Michigan, Mineralogical Society of America, 99-145.

McKenzie, D.P., O’Nions, R.K., 1991. Partial melt distributions from inversion of rare earth element concentrations. Journal of Petrology, 32, 1027-1091.

Millot, G., 1971. Geology of Clays. Weathering, Sedimentology, Geochemistry. Berlin, Springer-Verlag, 429pp.

De Min, A., Velicogna, M., Ziberna, L., Chiaradia, M., Alberti, A., Marzoli, A., 2020. Triassic magmatism in the European Southern Alps as an early phase of Pangea break-up. Geological Magazine, 157, 1800-1822.

Moore, D.M., Reynolds, R.C., 1997. X-Ray Diffraction and the Identification and Analysis of Clay Minerals. Oxford, University Press, 2nd edition, 378pp.

Morimoto, N., 1988. Nomenclature of pyroxenes. Schweizerische Mineralogische und Petrographische Mitteilungen, 68, 95-111.

Nave, D.A., Putirka, K.D., 2017. A new clinopyroxene-liquid barometer, and implications for magma storage pressures under Icelandic rift zones. American Mineralogist, 102, 777-794.

Neubauer, F., Liu, Y., Cao, S., Yuan, S., 2019. What is the Austroalpine mega-unit and what are the potential relations to Paleotethys Ocean remnants of southeastern Europe? Geologica Carpathica, 70, 16-20.

Nimis, P., 1999. Clinopyroxene geobarometry of magmatic rocks. Part 2: Structural geobarometers for basic to acid, tholeiitic and mildly alkaline magmatic systems. Contribution to Mineralogy and Petrology, 135, 62-74.

Nimis, P., Ulmer, P., 1998. Clinopyroxene geobarometry of magmatic rocks. Part 1: an expanded structural geobarometer 
for anhydrous and hydrous, basic and ultrabasic systems. Contribution to Mineralogy and Petrology, 133, 122-135.

Obenholzner, J.H., 1991. Triassic volcanogenic sediments from the Southern Alps (Italy, Austria, Yugoslavia)-a contribution to the "Pietra verde" problem. Sedimentary Geology, 74, 147-171.

Ogg, J.G., Ogg, G., Gradstein, FM., 2016. A concise geological time scale. Amsterdam, Elsevier, 250pp.

Pamić, J., 1984. Triassic magmatism of the Dinarides in Yugoslavia. Tectonophysics, 109, 273-307.

Pamić, J., 1997.Volcanic rocks from the Sava-Drava interfluve and Baranja in the south Pannonian basin (Croatia). Zagreb, Nafta, 192pp.

Pamić, J., Tomljenović, B., 1998. Basic geological data on the Croatian part of the Mid-Transdanubian Zone as exemplified by Mt. Medvednica located along the Zagreb-Zemplen Fault Zone. Acta Geologica Hungarica, 41, 389-400.

Pamić, J., 2002. The Sava-Vardar zone of the Dinarides and Hellenides versus the Vardar Ocean. Eclogae Geologicae Helvetiae, 9, 99-114.

Pamić, J., Balen, D., 2005. Interaction between Permo-Triassic rifting, magmatism and initiation of the Adriatic-Dinaridic carbonate platform (ADCP). Acta Geologica Hungarica, 48, 181-204.

Parry, W.T., Ballantyne, J.M., Jacobs, D.C., 1984. Geochemistry of hydrothermal sericite from Roosvelt Hot Springs and the Tintic and Santa Rita porphyry copper systems. Economic Geology, 79, 72-86.

Pearce, J.A., 1975. Basalt geochemistry used to investigate past tectonic environments on Cyprus. Tectonophysics, 25, 41-67.

Pearce, J.A., 1982. Trace element characteristics of lavas from destructive plate boundaries. In: Thorpe, R.S. (ed.). Andesites. New York, Wiley, 525-548.

Pearce, J.A., 1983. Role of the sub-continental lithosphere in magma genesis at active continental margins. In: Hawkesworth, C.J., Norry, M.J. (eds.). Continental basalts and mantle xenoliths. Nantwich UK, Shiva, 230-249.

Pearce, J.A., Lippard, S.J., Roberts, S., 1984. Characteristics and tectonic significance of supra-subduction zone ophiolites. In: Kokelaar, B.P., Howells, M.F. (eds.). Marginal Basin. Geology, Geological Society Special Publications, 16, 17-94.

Pearce, J.A., Parkinson, I.J., 1993. Trace element models for mantle melting: application to volcanic arc petrogenesis. In: Prichard, H.M., Alabaster, T. (eds.). Geological Society Special Publications, 76, 373-403.

Pe-Piper, G., 1998. The nature of Triassic extension-related magmatism in Greece: Evidence from $\mathrm{Nd}$ and $\mathrm{Pb}$ isotope geochemistry. Geological Magazine, 135, 331-348.

Philip, J., Masse, J-P., Camoin, G., 1995. Tethyan Carbonate Platforms. In: Nairn, A.E.M., Ricov, L.E., Vrielynck, B., Dércourt, J. (eds.). The ocean basins and margins, 8. New York, Plenum Press, 239-265.

del Piaz, G.V., Martin, S., 1998. Evoluzione litosferica e magmatismo nel dominio austro-sudalpino dall'orogenesi varisica al rifting permo-mesozoico. Riunione estiva S.G.I., Memoire della Societa Geologica Italiana, 53, 43-62.
Plank, T., Langmiur, C.H., 1998. The chemical composition of subducting sediment and its consequences for the crust and mantle. Chemical Geology, 145, 325-394.

Polat, A., Hofmann, A.W., Rosing, M.T., 2002. Boninite-like volcanic rocks in the $3.7-3.8 \mathrm{Ga}$ Isua greenstone belt, West Greenland: geochemical evidence for intra-oceanic subduction zone processes in the early Earth. Chemical Geology, 184, 231-254.

Polat, A., Hofmann, A.W., 2003. Alteration and geochemical patterns in the $3.7-3.8 \mathrm{Ga}$ Isua greenstone belt, West Greenland. Precambrian Research, 126, 197-218.

Pomonis, P., Tsikouras, V., Hatzipanagiotou, K., 2004. Comparative geochemical study of the Triassic trachyandesites of Glykomilia and alkali basalts from the Koziakas ophiolite mélange (W. Thessaly): implications for their origin. Bulletin of the Geological Society of Greece, 36, 587-596.

Pouchou, J.L., Pichoir, F., 1984. A new model for quantitative analyses. I. Application to the analysis of homogeneous samples. La Recherche Aérospatiale, 3, 13-38.

Pouchou, J.L., Pichoir, F, 1985. "PAP" ( $\square-\square-Z)$ correction procedure for improved quantitative microanalysis. In: Armstrong, J.T. (ed.). Microbeam Analysis. San Francisco Press, 104-106.

Putirka, K., 2008. Thermometers and Barometers for Volcanic Systems. Reviews in Mineralogy and Geochemistry, 69, 61-120.

Robertson, A.H.F, 2007. Overview of tectonic settings related to the rifting and opening of Mesozoic ocean basins in the Eastern Tethys: Oman, Himalayas and Eastern Mediterranean regions. London, Geological Society, 282 (Special Publications), 325-389.

Rollinson, H.R., 1993. Using geochemical data: evaluation, presentation, interpretation. Longman, 352pp.

Saccani, E., Dilek, Y., Marroni, M., Pandolfi, L., 2015. Continental margin ophiolites of Neotethys: Remnants of Ancient OceanContinent Transition Zone (OCTZ) lithosphere and their geochemistry, mantle sources and melt evolution patterns. Episodes, 38, 230-249.

Schmid, S.M., Fügenschuh, B., Kissling, E., Schuster, R., 2004. Tectonic map and overall architecture of the Alpine orogen. Eclogae Geologicae Helvetiae, 97, 93-117.

Schmid, S.M., Bernoulli, D., Fügenschuh, B., Matenco, L., Scheffer, S., Schuster, R., Tischler, M., Ustaszewski, K., 2008. The Alpine-Carpathian-Dinaridic orogenic system: correlation and evolution of tectonic units. Swiss Journal of Geosciences, 101, 139-183.

Schmid, S.M., Fügensschuh, B., Kounov, A., Matenco, M., Nievergelt, P., Oberhansli, R., Pleuger, J., Schefer, S., Schuster, R., Tomljenović, B., Ustaszewski, K., van Hinsbergen, D.J.J., 2019. Tectonic units of the Alpine collision zone between Eastern Alps and western Turkey. Gondwana Research, 78, 308-374.

Segnör, A.M.C., 1984. The Cimmeride orogenic system and the tectonics of Eurasia. Geological Society of America Special Papers, 195, 1-82. 
Šimunić, An., Šimunić, Al., 1979. Petrographic composition and genesis of Triassic deposits of Ivanščica (in Croatian, with English abstract). Kalnik and Ravna gora Mt. Geološki vjesnik, 32, 243-253.

Šimunić, An., 1992. Geological relations of the central part of the Croatian Zagorje (in Croatian, with English abstract). $\mathrm{PhD}$ Thesis. University of Zagreb, Zagreb, 189 pp.

Šimunić, An., Šimunić, Al., 1997. Triassic Deposits of Hrvatsko Zagorje. Geologia Croatica, 50, 243-250.

Sloman, L.E., 1989. Triassic shoshonites from the dolomites, northern Italy: alkaline arc rocks in a strike-slip setting. Journal of Geophysical Research-Solid Earth, 94, 4655-4666.

Slovenec, Da., Lugović, B., 2009. Geochemistry and tectonomagmatic affinity of extrusive and dyke rocks from the ophiolite mélange in the SW Zagorje-Mid-Transdanubian Zone (Mt. Medvednica, Croatia). Ofioliti, 34, 63-80.

Slovenec, Da., Lugović, B., Vlahović, I., 2010. Geochemistry, petrology and tectonomagmatic significance of basaltic rocks from the ophiolite mélange at the NW ExternalInternal Dinarides junction (Croatia). Geologica Carpathica, 61, 273-294.

Slovenec, Da., Lugović, B., Meyer, P., Garapić-Šiftar, G., 2011. A tectono-magmatic correlation of basaltic rocks from ophiolite mélanges at the north-eastern tip of the Sava-Vardar suture Zone, Northern Croatia, constrained by geochemistry and petrology. Ofioliti, 36, 77-100.

Slovenec, Da., Šegvić, B., Halamić, J., Goričan, Š., Zanoni, G., 2020. An ensialic volcanic arc along the northwestern edge of Palaeotethys-Insights from the Mid-Triassic volcanosedimentary succession of Ivanščica Mt. (northwestern Croatia). Geological Journal, 55, 4324-4351.

Smirčić, D., Kolar-Jurkovšek, T., Aljinović, D., Barudžija, U., Jurkovšek, B., Hrvatović, H., 2018. Stratigraphic definition and correlation of the Middle Triassic volcaniclastic facies in the External Dinarides: Croatia and Bosnia and Herzegovina. Journal of Earth Science, 29, 864-878.

Smirčić, D., Aljinović, D., Barudžija, U., Kolar-Jurkovšek, T., 2020. Middle Triassic syntectonic sedimentation and volcanic influence in the central part of the External Dinarides, Croatia (Velebit Mts.). Geological Quarterly, 64, 220-239.

Środoń, J., 2006. Identification and quantitative analysis of clay minerals. In: Bergaya, F., Theng, B., Lagaly, G. (eds.). Handbook of Clay Science. Amsterdam, Elsevier Ltd., 1, 765-787.

Stampfli, G.M., Mosar, J., Pillevuit, A., Vannay, J.C., 2001. PermoMesozoic evolution of the western Tethys realm: the NeoTethys East Mediterranean Basin connetion. In: Ziegler, P.A., Cavazza, W., Robertson, A.H.F, Crasquin-Soleau, S. (eds.). Peri-Tetys Memoir 6: Peri-Tethyan rift/wrench basins and passive margins. Mémories du Muséum National D‘Historie Naturalle, 186, 51-108.

Stampfli, G.M., Borel, G.D., 2002. A plate tectonic model for the Paleozoic and Mesozoic constrained by dynamic plate boundaries and restored synthetic ocean isochrons. Earth and Planetary Science Letters, 196, 17-33.
Stampfli, G.M., Borel, G.D., Marchant, R., Mosar, J., 2002. Western Alps geological constraints on western Tethyan reconstructions. Journal of the Virtual Explorer, 8, 77.

Stampfli, G.M., Borel, G.D., 2004. The TRANSMED transects in space and time: Constraints on the paleotectonic evolution of the Mediterranean domain. In: Cavazza, W., Roure, F, Spakman, W., Stampfli, G.M., Ziegler, P.A. (eds.). The TRANSMED Atlas: the Mediterranean Region from crust to mantle. Berlin, Springer-Verlag, 53-80.

Stampfli, C., Hochard, C., Vérard, C., Wilhem, J., Von Raumer, J.F, 2013. The formation of Pangea. Tectonophysics, 593, 1-19.

Staudigel, H., Plank, T., White, B., Schmincke, H.U., 1996. Geochemical fluxes during sea floor alteration of the basaltic upper oceanic crust: DSDP Sites 417 and 418. In: Bebout, E., Scholl, D.W., Kirby, S.H., Platt, J.P. (eds.). Subduction: Top to Bottom. American Geophysical Union Geophysical Monograph, 96, 19-38.

Storck, J.C., Brack, P., Wotzlaw, J.F, Ulmer, P., 2018. Timing and evolution of Middle Triassic magmatism in the Southern Alps (Northern Italy). London, Journal of Geological Society, 176, 253-268.

Sun, S.S., Nesbitt, R.W., 1978. Geochemical regularities and genetic significance of ophiolitic basalts. Geology, 6, 689-693.

Sun, S.S., McDonough, W.F., 1989. Chemical and isotopic systematics of oceanic basalts: implications for mantle composition and processes. In: Saunders, A.D., Norry, M.J. (eds.). Magmatism in Ocean Basins. London, Geological Society Special Publications, 42, 313-345.

Sun, S.C., Zhang, L., Li, R.H., Hao, T.W., Wang, J.Y., Li, Z.Q., Zhang, F., Zhang, X.J., Guo, H., 2019. Process and Mechanism of Gold Mineralization at the Zhengchong Gold Deposit, Jiangnan Orogenic Belt: Evidence from the Arsenopyrite and Chlorite Mineral Thermometers. Minerals, 9, 133. DOI: doi. org/10.3390/min9020133

Swinden, H.S., Jenner, G.A., Fryer, B.J., Hertogen, J., Roddick, J.C., 1990. Petrogenesis and paleotectonic history of the Wild Bight Group, an Ordovician rifted island arc in central Newfoundland. Contribution to Mineralogy and Petrology, 105, 219-241.

Tari, V., Pamić, J., 1998. Geodynamic evolution of the northern Dinarides and the southern part of the Pannonian Basin. Tectonophysics, 297, 269-281.

Taylor, S.R., McLennan, S.M., 1985. The continental crust: its composition and evolution. Oxford, Blackwell Scientific Publication, 312pp.

Taylor, S.R., McLennan, S.M., 1995. The geochemical evolution of the continental crust. Reviews of Geophysics, 33, 241-265.

Thirlwall, M.F, Upton, B.G.J., Jenkins, C., 1994. Interaction between continental lithosphere and the Iceland plume - $\mathrm{Sr}-$ $\mathrm{Nd}-\mathrm{Pb}$ isotope chemistry of Tertiary basalts, NE Greenland. Journal of Petrology, 35, 839-897.

Tillick, D.A., Peacor, D.R., Mauk, J.L., 2001. Genesis of dioctahedral phyllosilicates during hydrothermal alteration of volcanic rocks: I. The Golden Cross epithermal ore deposit, New Zealand. Clay Clay Minerals, 49, 126-140. 
Tišljar, J., 2004. Sedimentologija klastičnih i silicijskih taložina (in Croatian). Zagreb, Institut za geološka istraživanja, 426 pp.

Trubelja, F., Burgath, K.P., Marchig, V., 2004. Triassic magmatism in the area of the Central Dinarides (Bosnia and Herzegovina): Geochemical Resolving of tectonic setting. Geologia Croatica, 57, 159-170.

Velledits, F,, 2004. Anisian terrestrial sediments in the Bükk Mountains (NE Hungary) and their role in the Triassic rifting of the Vadar-Meliata branch of Neo-Tethys ocean. Rivista Italiana di Paleontologia e Stratigrafia, 110, 659-679.

Velledits, F, 2006. Evolution of Bükk Mountains (NE Hungary) during the Middle-Late Triassic asymmetric rifting of the Vadar-Meliata branch of the Neotethys Ocean. International Journal of Earth Sciences, 95, 395-412.

Vlahović, I., Tišljar, J., Velić, I., Matičec, D., 2005. Evolution of the Adriatic Carbonate Platform: Paleogeography, main events and depositional dynamics. Palaeogeography Palaeoclimatology Palaeoecology, 220, 333-360.

Walter, M.J., 1998. Melting of garnet peridotite and the origin of komatiite and depleted lithosphere. Journal of Petrology, 39, 29-60.

Wang, Z., Chen, B., Yan, X., Li, S., 2018. Characteristics of hydrothermal chlorite from the Niujuan $\mathrm{Ag}-\mathrm{Au}-\mathrm{Pb}-\mathrm{Zn}$ deposit in the north margin of NCC and implications for exploration tools for ore deposits. Ore Geology Review, 101, 398-412.

White, W.M., Patchett, P.J., 1984. Hf-Nd-Sr isotopes and incompatible-element abundances in island arcs, and implications for magma origins and crust-mantle evolution. Earth and Planetary Science Letters, 67, 167-185.

Wilson, M., 1989. Igneous petrogenesis. London, Unwin Hyman Ltd., 466pp.

Wilson, M., Downes, H., Cebria, J.M., 1995. Contrasting fractionation trends in coexisting continental alkaline magma series: Cantal, Massif Central, France. Journal of Petrology, 36, 1729-1753.

Winchester, J.A., Floyd, P.A., 1977. Geochemical discrimination of different magma series and their differentiation products using immobile elements. Chemical Geology, 20, 325-343.
Wood, D.A., 1980. The application of a Th-Hf-Ta diagram to problems of tectonomagmatic classification and establishing the nature of crustal contamination of basaltic lavas of the British Tertiary volcanic province. Earth and Planetary Science Letters, 50, 11-30.

Workman, R.K., Hart, S.R., 2005. Major and trace element composition of the depleted MORB mantle (DMM). Earth and Planetary Science Letters, 231, 53-72.

Zane, A., Weiss, Z.A., 1998. Procedure for classifying rockforming chlorites based on microprobe data. Rendiconti Lincei, 9, 51-56.

Zanetti, A., Mazzucchelli, M., Sinigoi, S., Giovanardi, T., Peressini, G., Fanning, M., 2013. SHRIMP U-Pb Zircon Triassic intrusion age of the Finero mafic complex (Ivrea-Verbano zone, Western Alps) and its geodynamic implications. Journal of Petrology, 54, 2235-2265.

Zanoni, G., Šegvić, B., Moscariello, A., 2016. Clay mineral diagenesis in Cretaceous clastic reservoirs from West African passive margins (the South Gabon Basin) and its impact on regional geology and basin evolution history. Applied Clay Science, 134, 186-209.

Ziegler, P.A., Stampfli, G.M., 2001. Late Paleozoic-early Mesozoic plate boundary reorganization: collapse of the Variscan orogen and opening of Neotethys. Natura Bresciana Annales Museo Civico Science Natura, 25 (Monografia), 17-34.

Zindler, A., Hart, S., 1996. Chemical geodynamics. Annual Review of Earth and Planetary Sciences, 14, 493-571.

Zulauf, G., Dörr, W., Fisher-Spurlock, S.C., Gerdes, A., Chatzaras, V., Xypolias, P., 2015. Closure of the Paleotethys in the External Hellenides: Constraints from $\mathrm{U}-\mathrm{Pb}$ ages of magmatic and detrital zircons (Crete). Gondwana Research, 28, 642-667.

Zulauf, G., Dörr, W., Marko, L., Krahl, J., 2018. The late EoCimmerian evolution of the external Hellenides: constraints from microfabrics and $\mathrm{U}-\mathrm{Pb}$ detrital zircon ages of Upper Triassic (meta)sediments (Crete, Greece). International Journal of Earth Sciences, 107, 2859-2894.

\footnotetext{
Manuscript received July 2020; revision accepted December 2020; published Online March 2021.
} 